PRACE GEOGRAFICZNE

zeszyt $161,2020,81-106$

doi: 10.4467/20833113PG.20.009.12551

Instytut Geografii i Gospodarki Przestrzennej UJ

Komisja Geograficzna, Polska Akademia Umiejętności

Wydawnictwo Uniwersytetu Jagiellońskiego

\title{
LOKALIZACJA WSPÓŁCZESNYCH CMENTARZY KOMUNALNYCH W POLSCE
}

Anna Dtugozima

\section{Location of contemporary communal cemeteries in Poland}

Abstract: The main purpose of this paper is to characterise contemporary communal cemeteries and to develop a typology of these facilities from the point of view of its location. The main criteria for the selection of cemeteries were the date of creation (1999-2019) and the communal status of objects. Literature studies in the fields of spatial planning, landscape architecture, geography, sociology and an analysis of legal acts including planning acts were the bases for developing evaluation criteria in the aspect of cemeteries location. The location of cemeteries in relation to: natural system, accessibility, functional and spatial structure of settlement units and religious facilities was characterized. The spatial extent of the research covered cemeteries within their boundaries along with the sanitary protection zone $(150 \mathrm{~m})$. Field studies were carried out in July and August 2019. The research showed that out of 63 cemeteries, most are established within the administrative boundaries of cities, but in their suburban, non-urbanized areas. Models of communal cemeteries were developed due to their location.

Keywords: cemetery, location criterion, protection zone, functional and spatial structure

Zarys treści: Celem artykułu jest charakterystyka budowanych współcześnie w Polsce cmentarzy komunalnych $\mathrm{z}$ uwzględnieniem kryterium lokalizacji. Badaniami objęto cmentarze o statusie obiektu komunalnego, zakładane w latach 1999-2019. Aby scharakteryzować lokalizację współczesnego cmentarza, na podstawie kwerendy materiałów źródłowych (przepisy prawa, literatura z zakresu gospodarki przestrzennej, architektury krajobrazu, geografii, socjologii), określono kryteria, według których rozpatrywano położenie cmentarza, tj. system przyrodniczy, dostępność komunikacyjna, obiekty religijne, struktura funkcjonalno-przestrzenna jednostek osadniczych. Zasięg przestrzenny badań objął cmentarze w ich granicach 
wraz ze strefą ochrony sanitarnej $(150 \mathrm{~m})$. Wizję terenową przeprowadzono w lipcu i sierpniu 2019 r. Badania wykazały, że spośród 63 cmentarzy większość zakładana jest w granicach administracyjnych miast, ale na terenach o charakterze podmiejskim, niezurbanizowanym. Opracowano modele lokalizacji cmentarzy komunalnych.

Stowa kluczowe: cmentarz, kryterium lokalizacji, strefa ochronna, struktura funkcjonalnoprzestrzenna

\section{Wstęp}

\section{Stan badań na temat cmentarzy}

Dotąd nie prowadzono w Polsce kompleksowych badań, których celem byłaby identyfikacja i ocena współczesnych cmentarzy komunalnych w aspekcie ich położenia. Podjęcie niniejszego tematu zdeterminowały: raport Najwyższej Izby Kontroli (2016) i wykazane w nim problemy związane z zarządzaniem cmentarzami komunalnymi oraz prognozy demograficzne publikowane przez Główny Urząd Statystyczny, z których wynika, że liczba ludności w Polsce zmniejszy się z 38,5 mln w 2018 r. do 34,8 mln w 2050 r. Mimo postępu w medycynie, który przyczynia się do stałej, znaczącej redukcji umieralności i prowadzi do permanentnego wydłużania długości życia, wszystkie prognozy zakładają powolny wzrost liczby zgonów, w fazę wieku poprodukcyjnego wkracza bowiem ludność powojennego wyżu (Szukalski 2016). Ważnym impulsem uzasadniającym podjęcie badań jest brak centralnej bazy danych agregującej informacje o cmentarzach. Tymczasem na świecie dane odnoszące się do typu (wyznaniowy/komunalny), statusu (czynny/nieczynny) i rozmieszczenia cmentarzy stanowią podstawę w zakresie ich planowania, w tym także określania lokalizacji (Croucamp, Richards 2002; Kjøller 2012, 2013; Santarsiero i in. 2000; Tudor i in. 2013; Van Steen, Pellenbarg 2006).

\section{Uwarunkowania lokalizacji i procedura zakładania cmentarzy komunalnych}

W Polsce rozróżnia się cmentarze cywilne, na których chowane są osoby cywilne, oraz cmentarze wojskowe, stanowiące miejsce spoczynku żołnierzy. Cmentarze wojskowe podlegają zapisom Ustawy o grobach i cmentarzach wojennych (Dz. U. 1933, $\mathrm{Nr}$ 39, poz. 311). Z kolei Ustawa o cmentaræach i chowaniu smartych (Dz. U. 1959, $\mathrm{Nr}$ 11, poz. 62) reguluje zasady planowania i funkcjonowania cmentarzy cywilnych, rozróżniając ich dwa rodzaje: wyznaniowe oraz komunalne (Sobczak 2003). Przedmiotem zainteresowania na potrzeby niniejszych badań są cmentarze komunalne. Zgodnie z przepisami cmentarze komunalne to obiekty, które zostały założone 
przez władze samorządowe i nie zostały przekazane właściwej władzy kościelnej oraz które są utrzymywane i zarządzane przez właściwego wójta (burmistrza, prezydenta miasta). Katalog uwarunkowań determinujących zakładanie cmentarzy zmieniał się wraz z rozwojem historycznym (Ariès 1989; Tanaś 2008). Za najistotniejsze uznaje się uwarunkowania społeczno-kulturowe, przestrzenne oraz prawne (ryc. 1).

Uwarunkowania społeczno-kulturowe w zakresie planowania lokalizacji cmentarzy związane są z utożsamianiem cmentarzy z miejscem realizowania kultu religijnego (Pogodziński 1975). W ramach tych uwarunkowań uwzględnia się również: percepcję śmierci; rolę i znaczenie nadawane cmentarzom przez społeczeństwo; stosunek społeczeństwa do kremacji (pochówek urnowy zajmuje ułamek miejsca potrzebnego do pochówku trumnowego, co skutkuje większą oszczędnością terenu) (Długozima 2011; Stępa 1993); współczynnik umieralności, który determinuje dynamikę zapełniania się przestrzeni grzebalnej i ewentualną konieczność rozbudowy lub poszukiwania nowej

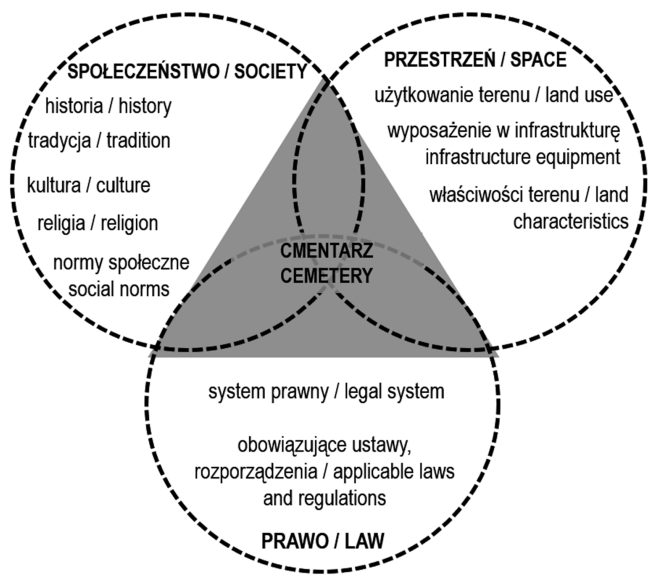

Ryc. 1. Uwarunkowania determinujące zakładanie cmentarzy

Fig. 1. Conditions for the establishment of cemeteries

lokalizacji dla cmentarza. Uwarunkowania przestrzenne powiązane są ze sposobem i jakością zagospodarowania przestrzeni oraz jej wyposażeniem w infrastrukturę. Uwarunkowania prawne dotyczą obowiązujących w Polsce przepisów prawnych w zakresie zakładania i utrzymania cmentarzy. Podstawowymi aktami regulującymi te kwestie są: Ustawa z 31 stycznia 1959 o cmentar ach i chowaniu zmartych (Dz. U. 1959, Nr 11, poz. 62), Rozporsqdzenie Ministra Gospodarki Komunalnej z 25 sierpnia 1959 roku w sprawie określenia, jakie tereny pod wagledem sanitarnym sq odpowiednie na cmentar:e (Dz. U. 1959, Nr 52, poz. 315), Rosporzadzenie Ministra Infrastruktury ะ dnia 7 marca 2008 roku w sprawie wymagań, jakie muszq spetniać cmentarze, groby i inne miejsca pochówku zwtok i szczqtkow (Dz. U. 2008, Nr 48, poz. 284), Ustawa Prawo budowlane z dnia 7 lipca 1994 roku (Dz. U. 1994, Nr 89, poz. 414), Ustawa o ochronie przyrody z dnia 16 kwietnia 2004 roku (Dz. U. 2004, Nr 92, poz. 880). Wyżej wymienione akty prawne regulują dystans od terenów zabudowanych, przeznaczenie terenów sąsiadujących oraz niezbędne elementy zagospodarowania cmentarzy. Ponadto, w związku 
z uznawaniem cmentarzy za tereny zieleni przepisy określają parametry i właściwości gruntów predestynowanych na cmentarze. Determinują także etapowanie procesu zakładania cmentarzy (tab. 1).

Tab. 1. Zestawienie przepisów prawnych warunkujących lokalizację i zakładanie cmentarzy w Polsce

Table 1. Summary of law regulations determining the location and establishment of Polish cemeteries

\begin{tabular}{|c|c|c|}
\hline \multicolumn{2}{|c|}{$\begin{array}{c}\text { Przepisy prawne określające zakładanie cmentarzy komunalnych w Polsce } \\
\text { Legal provisions on the location of communal cemeteries }\end{array}$} & $\begin{array}{l}\text { Źródła prawa } \\
\text { Source of law }\end{array}$ \\
\hline \multirow{4}{*}{$\begin{array}{l}\text { Etapy inwestycji } \\
\text { Investment } \\
\text { stages }\end{array}$} & $\begin{array}{l}\text { FAZA DECYZJI: wykonanie dokumentacji geotechnicznej uwzględniającej } \\
\text { właściwości gruntów, stosunki wodne, głębokość i zmienność poziomu } \\
\text { wód gruntowych, istniejące zespoły roślinne; decyzja Państwowego } \\
\text { Powiatowego Inspektoratu Sanitarnego właściwego ze względu na } \\
\text { miejsce inwestycji; wskazanie terenu na cmentarz (ZC) w miejscowym } \\
\text { planie zagospodarowania przestrzennego; } \\
\text { DECISION PHASE: undertaking geotechnical surveys to determine soil } \\
\text { physical factors, water regime, plant communities; decision of the State } \\
\text { Poviat Sanitary Inspectorate; indication of cemetery location (ZC) in the } \\
\text { local land use plan; }\end{array}$ & \multirow{4}{*}{$\begin{array}{l}\text { Dz. U. 1959, } \\
\text { Nr 11, poz. } 62 \\
\text { Dz. U. 1959, } \\
\text { Nr 52, poz. } 315 \\
\text { Dz. U. 2003, } \\
\text { Nr 120, poz. } 1133 \\
\text { Dz. U. 2003, } \\
\text { Nr } 164, \text { poz. } 1587 \\
\text { Dz.U. } 2003 \text { nr } 80 \\
\text { poz. } 717\end{array}$} \\
\hline & $\begin{array}{l}\text { FAZA PRZYGOTOWANIA DOKUMENTACJI (FAZA PRZEDPROJEKTOWA): } \\
\text { opracowanie założeń do projektu; pozyskanie materiałów wyjściowych } \\
\text { (mapa zasadnicza do celów projektowych); ogłoszenie konkursu, rozpo- } \\
\text { częcie procedury przetargowej na opracowanie projektu, negocjacje; } \\
\text { DOCUMENTATION PREPARATION PHASE (PRE-DESIGN PHASE): } \\
\text { developing project assumptions; collecting data about area (base map } \\
\text { for design purposes); announcement of the competition/tendering for } \\
\text { cemetery project; }\end{array}$ & \\
\hline & $\begin{array}{l}\text { FAZA PROJEKTOWA: projekt koncepcyjny, ustalenie i uzgodnienia } \\
\text { z odpowiednimi jednostkami administracji państwowej, projekt budow- } \\
\text { lany i wykonawczy, pozwolenie na budowę; } \\
\text { DESIGN PHASE: concept; legal assessments; preparation of tender } \\
\text { procedures for the execution of design and construction works } \\
\text { and contracts related to these proceedings; counselling services } \\
\text { connected with the investment preparation; }\end{array}$ & \\
\hline & $\begin{array}{l}\text { FAZA REALIZACJI: realizacja inwestycji na podstawie umowy zawartej } \\
\text { między inwestorem a wykonawcą, projekt organizacji budowy, zakończe- } \\
\text { nie inwestycji i oddanie do użytku (aby otrzymać zgodę na użytkowanie } \\
\text { cmentarza niezbędne jest usunięcie wszelkich kolizji, np. ze słupami } \\
\text { elektroenergetycznymi); } \\
\text { IMPLEMENTATION PHASE: project under construction on the basis } \\
\text { of a construction contract, organization of construction site, facilities } \\
\text { acceptance (to receive valid occupancy permit removing colliding power } \\
\text { lines is necessary); }\end{array}$ & \\
\hline
\end{tabular}




\begin{tabular}{|c|c|c|}
\hline \multicolumn{2}{|c|}{$\begin{array}{l}\text { Przepisy prawne określające zakładanie cmentarzy komunalnych w Polsce } \\
\text { Legal provisions on the location of communal cemeteries }\end{array}$} & $\begin{array}{l}\text { Źródła prawa } \\
\text { Source of law }\end{array}$ \\
\hline $\begin{array}{l}\text { Właściwości } \\
\text { przestrzenne } \\
\text { terenu na cele } \\
\text { grzebalne } \\
\text { Spatial } \\
\text { characteristics } \\
\text { of burial ground }\end{array}$ & $\begin{array}{l}\text { - Lokalizacja wykluczająca możliwość wywierania szkodliwego wpływu } \\
\text { cmentarza na otoczenie / Location excluding possibility of harmful } \\
\text { impact of cemetery on vicinity; } \\
\text { - Tereny na krańcach miast, osiedli lub gromad w izolacji od zabudo- } \\
\text { wań, na gruntach przeznaczonych pod zieleń publiczną lub odpowied- } \\
\text { nich na jej urządzenie, w pobliżu miejscowej sieci komunikacyjnej } \\
\text { Areas on the outskirts of settlement units, in isolation from building, } \\
\text { on land predestined for public greenery or suitable for its device, near } \\
\text { to the local transport system; } \\
\text { - Odległość } 150 \text { m od zakładów produkujących artykuły żywności, } \\
\text { zakładów żywienia zbiorowego bądź zakładów przechowujących artykuły } \\
\text { żywności oraz studni, źródeł i strumieni, służących do czerpania wody } \\
\text { do picia i potrzeb gospodarczych / Distance of } 150 \mathrm{~m} \text { from nutrition } \\
\text { enterprises, food storage facilities or water intakes; } \\
\text { - Odległość } 50 \mathrm{~m} \text {, gdy teren w granicach od } 50 \text { do } 150 \mathrm{~m} \text { odległości } \\
\text { od cmentarza jest wyposażony w sieć wodociagową i wszystkie budynki } \\
\text { korzystające z wody są do tej sieci podłączone / Distance } 50 \mathrm{~m} \text {, when } \\
\text { the area within } 50 \text { to } 150 \mathrm{~m} \text { distance from the cemetery is equipped with } \\
\text { a water supply network and all buildings using water are connected } \\
\text { to this network; }\end{array}$ & $\begin{array}{l}\text { Dz. U. 1959, } \\
\text { Nr 52, poz. } 315\end{array}$ \\
\hline $\begin{array}{l}\text { Właściwości } \\
\text { przyrodnicze } \\
\text { terenu na cele } \\
\text { grzebalne } \\
\text { Natural } \\
\text { characteristics } \\
\text { of burial ground }\end{array}$ & $\begin{array}{l}\text { - Na wzniesieniu, niepodlegający zalewom / On hill, not liable to } \\
\text { flooding; } \\
\text { - Łatwy spływ wód deszczowych / Easy water run-off; } \\
\text { - Zwierciadło wody gruntowej na głębokości nie wyższej niż } 2,5 \mathrm{~m} \\
\text { poniżej powierzchni terenu, przy czym nie może być ono nachylone } \\
\text { ku zabudowaniom lub ku zbiornikom lub innym ujęciom wody służącym } \\
\text { za źródło zaopatrzenia w wodę do picia i na potrzeby gospodarki / Water } \\
\text { table not more than } 2.5 \mathrm{~m} \text { below the ground surface, however it cannot } \\
\text { be inclined towards buildings, water intakes; } \\
\text { - Grunt cmentarza możliwie przepuszczalny i bez zawartości węglanu } \\
\text { wapnia / Soil possibly permeable and not containing calcium carbonat; } \\
\text { - Najczęściej spotykane wiatry powinny wiać od terenów mieszka- } \\
\text { niowych w kierunku cmentarza / Most frequent wind directions from } \\
\text { residential areas towards the cemetery. }\end{array}$ & $\begin{array}{l}\text { Dz. U. 1959, } \\
\text { Nr 52, poz. } 315\end{array}$ \\
\hline
\end{tabular}

\section{Wielowymiarowość cmentarzy}

Oprócz swojej podstawowej funkcji, którą jest bycie miejscem pochówku, cmentarze spełniają szereg innych zadań. Odgrywają m.in. istotną rolę kulturotwórczą: jako miejsce sacrum (Harvey 2006; Swaryczewska 2008), miejsce upamiętniające 
o charakterze refleksyjno-kontemplacyjnym i terapeutycznym (Długozima 2011; Rugg 2000), miejsce społeczne (Francaviglia 1971; Francis 2003; Kolbuszewski 1996; Lewicka 2017), przestrzeń publiczna, ogólnodostępna (Ptaszycka 1950; Piątkowska 1983; Szumański 2005; Solarek 2009). Jednocześnie mają znaczenie krajobrazowe oraz przyrodnicze - są ważnym elementem wspomagającym funkcjonowanie środowiska przyrodniczego (Abernathy 1970; Długozima, Kosiacka-Beck 2020; Gilbert 1991; Laske 1994). Z uwagi na swoją specyfikę odróżniają się od innych kategorii użytkowania gruntów i wymagają zapewnienia przemyślanej, określonej przestrzeni dla prawidłowej realizacji swych funkcji (Capels, Senville 2006; Lehrer 1974). Na podstawie analizy literatury przedmiotu i przepisów prawnych cmentarze należy uznać za tereny zieleni, tereny publiczne, obiekty budowlane oraz obiekty religijne jednocześnie (ryc. 2). Wielowymiarowość cmentarzy wpływa na konieczność prowadzenia wieloaspektowych, zintegrowanych analiz celem wskazania najbardziej optymalnego terenu na ich lokalizację.

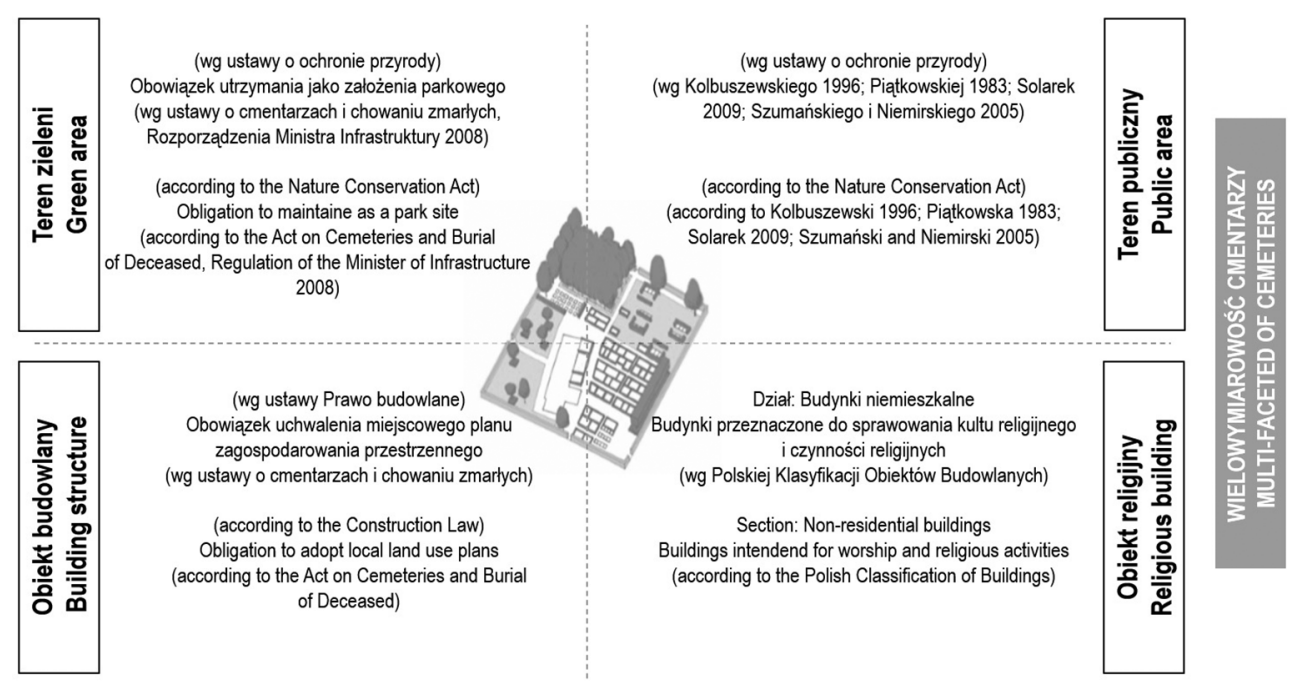

Ryc. 2. Schemat przedstawiający wielowymiarowość cmentarzy oraz aspekty, które należy uwzględnić przy określaniu czynników lokalizacji tych obiektów

Fig. 2. Diagram showing the multiperspective character of cemeteries and the aspects that should be considered when determining the location factors of these objects 


\section{Material i metody}

\section{Postępowanie badaweze}

Celem badań była ocena lokalizacji budowanych współcześnie cmentarzy komunalnych w kontekście dostępności komunikacyjnej (cmentarz jako teren publiczny), położenia względem obiektów religijnych (cmentarz jako obiekt religijny), systemu przyrodniczego (cmentarz jako teren zieleni) oraz struktury funkcjonalno-przestrzennej jednostek osadniczych (cmentarz jako obiekt budowlany). Poddane ocenie czynniki lokalizacji opracowano na podstawie analizy literatury przedmiotu, przepisów prawa obowiązujących w Polsce, badań terenowych oraz analiz przestrzennych wykonanych dla 63 wybranych cmentarzy (tab. 3). Postępowanie badawcze objęło 3 etapy: identyfikacja cmentarzy - obiektów badawczych, zdefiniowanie czynników lokalizacji cmentarzy, opracowanie modeli lokalizacji cmentarzy (tab. 2).

Tab. 2. Schemat postępowania badawczego

Table 2. Research flowchart

\begin{tabular}{|c|c|c|}
\hline \multicolumn{3}{|c|}{$\begin{array}{l}\text { Lokalizacja współczesnych cmentarzy komunalnych w Polsce } \\
\text { Location of communal cemeteries in Poland }\end{array}$} \\
\hline \multicolumn{3}{|c|}{$\downarrow$} \\
\hline $\begin{array}{l}\text { Etap } \\
\text { Phase of studies }\end{array}$ & $\begin{array}{c}\text { Cel } \\
\text { Purpose of studies }\end{array}$ & $\begin{array}{c}\text { Metoda } \\
\text { Research methodology }\end{array}$ \\
\hline 1 & $\begin{array}{l}\text { Identyfikacja współczesnych cmentarzy } \\
\text { komunalnych } \\
\text { Identification of contemporary communal } \\
\text { cemeteries }\end{array}$ & $\begin{array}{l}\text { Przegląd źródeł internetowych, } \\
\quad \text { agregowanie danych } \\
\text { Websites review, data collection }\end{array}$ \\
\hline \multicolumn{3}{|c|}{$\downarrow$} \\
\hline 2 & $\begin{array}{l}\text { Zdefiniowanie czynników lokalizacji cmentarzy } \\
\text { Defining factors of cemeteries location }\end{array}$ & $\begin{array}{l}\text { Analiza literatury przedmiotu, } \\
\text { przepisów prawa } \\
\text { Literature and law } \\
\text { regulations review }\end{array}$ \\
\hline \multicolumn{3}{|c|}{$\downarrow$} \\
\hline 3 & $\begin{array}{l}\text { Opracowanie modeli lokalizacji cmentarzy } \\
\text { Developing models of cemeteries location }\end{array}$ & $\begin{array}{c}\text { Badania terenowe, analiza } \\
\text { dokumentów planistycznych, } \\
\text { analizy przestrzenne } \\
\text { Field studies, analysis of spatial policy } \\
\text { documents, spatial analysis }\end{array}$ \\
\hline
\end{tabular}




\section{Identyfikacja współczesnych ementarzy komunalnych}

Ponieważ w Polsce nie prowadzi się rejestru cmentarzy, identyfikacji obiektów badawczych dokonano na podstawie przeglądu portali samorządowych, stron internetowych (hasła „nowy cmentarz”, „budowa cmentarza”), czasopism branżowych („Memento”, „Kultura Pogrzebu”), danych Powiatowych Stacji Sanitarno-Epidemiologicznych, Polskiego Stowarzyszenia Pogrzebowego oraz Banku Danych Lokalnych Głównego Urzędu Statystycznego (BDL GUS). Badaniami objęto cmentarze o statusie obiektu komunalnego, zakładane w latach 1999-2019, zlokalizowane na terenie wszystkich województw (63 cmentarze). W badaniach uwzględniono obiekty zrealizowane.

\section{Zdefiniowanie czynników lokalizacji ementarzy}

Analiza literatury przedmiotu dotyczącej cmentarzy pozwoliła wskazać uwarunkowania determinujące proces zakładania, lokalizacji i zagospodarowywania cmentarzy w Polsce (uwarunkowania społeczno-kulturowe, przestrzenne oraz prawne). Te wpływają na wielowymiarowość tych obiektów. Rozumienie ich przez polskie przepisy i tradycję jednocześnie jako tereny zieleni, tereny publiczne, obiekty budowlane i obiekty kultu religijnego przełożyło się na wygenerowanie czterech grup czynników lokalizacji, tj. czynników infrastrukturalnych, funkcjonalno-przestrzennych, społeczno-kulturowych oraz ekologicznych. Przy wyborze czynników lokalizacji pomocne były także raporty: American Planning Association (1950) i Syndicat Intercommunal Funéraire de la Région Parisienne-SIFUREP (2009). Na tej podstawie wyodrębniono następujące grupy czynników lokalizacji cmentarzy: infrastrukturalne (dostępność komunikacyjna), funkcjonalno-przestrzenne (położenie w strukturze funkcjonalnej i przestrzennej jednostek osadniczych), ekologiczne (położenie w systemie przyrodniczym) oraz społeczno-kulturowe (położenie względem obiektów religijnych) (ryc. 3).

\section{Cisyniki infrastrukturalne}

Teren cmentarza jest predestynowany do zaspokojenia potrzeb zbiorowych ludności w zakresie stworzenia godnego miejsca dla pochówku oraz kultu pamięci osób zmarłych (Kolbuszewski 1996). Rozporzqdzenie Ministra Infrastruktury z dnia 7 marca 2008 roku... (Dz. U. 2008, Nr 48, poz. 284) podkreśla, że do cmentarza należy zapewnić dojścia i dojazdy, co warunkuje, by przy lokowaniu nekropolii uwzględniać kryterium dostępności komunikacyjnej.

\section{Cizynniki funkcjonalno-przestrzenne}

Cmentarze mogą funkcjonować tylko na terenie, dla którego uchwalono miejscowy plan zagospodarowania przestrzennego. Ponadto, ze względu na chrześcijańską tra- 


\section{UWARUNKOWANIAZAKLADANIA CMENTARZY / CONDITIONS FOR CEMETERIES ESTABLISHMENT}

\section{WIELOWYMIAROWOŚĆ CMENTARZY I MULTI-FACETED OF CEMETERIES}

\section{CZYNNIKI LOKALIZACJI CMENTARZY I FACTORS OF CEMETERIES LOCATION}

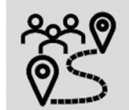

\section{INFRASTRUKTURALNE / INFRASTRUCTURAL}

Dostępność komunikacyjna cmentarzy / Transport accessibility of cemeteries

\section{FUNKCJONALNO-PRZESTRZENNE / FUNCTIONAL AND SPATIAL}

뭄돈

Położenie cmentarzy w strukturze przestrzennej / Location of cemeteries in spatial structure Położenie cmentarzy względem funkcji terenu i zabudowy / Location of cemeteries in relation to the function of the area and buildings

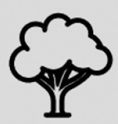

\section{EKOLOGICZNE / ECOLOGICAL}

Położenie cmentarzy względem systemu przyrodniczego / Location of cemeteries in relation to the city's natural system

\section{SPOLECZNO-KULTUROWE / SOCIO-CULTURAL}

Położenie cmentarzy względem obiektów religijnych / Location of cemeteries in relation to religious facilities

Ryc. 3. Czynniki lokalizacji cmentarzy jako wynikowa uwarunkowań zakładania i wielowymiarowości cmentarzy

Fig. 3. Factors of cemeteries location as a result of the conditions and multiperspective of cemeteries

dycję organizacji cmentarzy, przestrzeniom tym należy się estyma. Ciszy i spokoju nie powinny zakłócać obiekty prowadzące działalność rozrywkową, zakłady usługowo-przemysłowe emitujące ponadnormatywny hałas, odory i zanieczyszczenia (Chudak 2012). Zgodnie z Ustawq Prawo budowlane (Dz. U. 1994, Nr 89, poz. 414) cmentarz jest zaliczany do budowli (obiektów budowlanych niebędących budynkiem lub obiektem małej architektury, art. 3). W związku z powyższym ważną kwestią jest położenie w strukturze funkcjonalno-przestrzennej jednostki osadniczej oraz zagospodarowanie otoczenia cmentarza. 


\section{Caynniki ekologiczne}

Zgodnie z zapisami Ustawy o ochronie przyrody (Dz. U. 2004, Nr 92, poz. 880) do terenów zieleni zalicza się także cmentarze. Są one bardzo ważnym uzupełnieniem zieleni publicznej. W niektórych państwach europejskich obowiązuje wymóg wpisywania cmentarzy w system przyrodniczy, np. w Niemczech (Richter 1995), dlatego istotne jest zweryfikowanie położenia cmentarzy względem tego systemu.

\section{Czynniki spoteczno-kulturowe}

Miejsca religijne - zarówno kościół, jak i cmentarz - mają wysoki status w hierarchizacji przestrzeni (Swaryczewska 2008), co podkreśla m.in. Polska Klasyfikacja Obiektów Budowlanych (Dz. U. 1999, Nr 112, poz. 1316). Budynki przeznaczone do sprawowania kultu religijnego i czynności religijnych (klasa 1272) to m.in.: cmentarze i obiekty z nimi związane, co determinuje ocenę położenia cmentarzy względem obiektów religijnych.

\section{Opracowanie modeli lokalizacji cmentarzy}

Aby scharakteryzować lokalizację współczesnych cmentarzy komunalnych (tab. 3) dla wypracowanych czterech grup czynników (ryc. 3), zastosowano określone kryteria wraz z metodami badawczymi. Wszystkie analizy poprzedzono badaniami terenowymi przeprowadzonymi w lipcu i sierpniu 2019 r. Następnie dokonano rozpoznania i oceny 63 obiektów pod kątem: podstawowych cech (powierzchnia, rok oddania do użytku), położenia względem systemu komunikacji, systemu przyrodniczego, struktury przestrzennej, funkcjonalnej oraz obiektów religijnych, uwzględniając, zgodnie z zapisami Ustawy o cmentarsach $i$ chowaniu smartych, maksymalny zasięg strefy ochrony sanitarnej, tj. $150 \mathrm{~m}$.

Wykonując analizy przestrzenne, skorzystano z narzędzi analitycznych QGIS (np. pomiary odległości, powierzchni, buforowanie, generowanie schwarzplanu) (Michalak 2007; Bednarczyk, Rapiński 2011). Wykorzystano dane przestrzenne ze strony OpenStreetMap oraz bazę danych obiektów topograficznych BDOT10k. Biorąc pod uwagę dostępność komunikacyjną, przeprowadzono analizę dostępności do publicznych środków transportu zbiorowego i analizę dostępności mierzonej wyposażeniem infrastrukturalnym (Komornicki i in. 2009; Śleszyński 2014). Badanie struktury funkcjonalno-przestrzennej pozwala określić, w otoczeniu jakich terenów, o jakim przeznaczeniu i charakterze cmentarze są zlokalizowane. W związku z tym uwzględniono: relację cmentarz-centrum miejscowości, ziarnistość (Ziobrowski 2012) (wielkość poszczególnych elementów występujących wokół cmentarza, opracowując schwarzplany), postrzegalność obiektów (Balon 2005; Długozima 2011) oraz funkcje terenów. 
Tab. 3. Zestawienie nowych cmentarzy komunalnych

Table 3. List of new municipal cemeteries

\begin{tabular}{|c|c|c|c|}
\hline \multirow{2}{*}{$\begin{array}{l}\text { Województwo } \\
\text { Voivodeship }\end{array}$} & \multicolumn{3}{|c|}{ CMENTARZE KOMUNALNE 1999-2019 / COMMUNAL CEMETERIES 1999-2019 } \\
\hline & $\begin{array}{l}\text { Liczba } \\
\text { Number }\end{array}$ & $\begin{array}{l}\text { Łączna pow. [ha] } \\
\text { Total area [ha] }\end{array}$ & Wykaz (rok) / List of communal cemeteries (year) \\
\hline Dolnośląskie & 7 & 62,9 & $\begin{array}{l}\text { 1) Borzygniew (2003), 2) Jaszków (2013), 3) Jelenia Góra (2000), } \\
\text { 4) Nowogrodziec (2011), 5) Smolec (2018), 6) Strzegom (2012), } \\
\text { 7) Żeleźnik (2015) }\end{array}$ \\
\hline $\begin{array}{l}\text { Kujawsko- } \\
\text {-pomorskie }\end{array}$ & 4 & 29,0 & $\begin{array}{l}\text { 8) Brodnica (1999), 9) Grudziądz-Kobylanka (2002), 10) Nowa } \\
\text { Chełmża (2004), 11) Starorypin Prywatny (2006) }\end{array}$ \\
\hline Lubelskie & 6 & 21,9 & $\begin{array}{l}\text { 12) Kobylany (2019), 13) Łuków (2016), 14) Międzyrzec Podlaski } \\
\text { (2000), 15) Opole Lubelskie (2014), 16) Rejowiec (2002), } \\
\text { 17) Stara Wieś (2009) }\end{array}$ \\
\hline Lubuskie & 1 & 12,8 & 18) Zielona Góra (2008) \\
\hline Łódzkie & 2 & 2,1 & 19) Opoczno (2016), 20) Wieluń (2010) \\
\hline Małopolskie & 3 & 41,0 & $\begin{array}{l}\text { 21) Nowy Targ (2016), 22) Rdziostów (2016), 23)Tarnów Klikowa } \\
\text { (2008) }\end{array}$ \\
\hline Mazowieckie & 5 & 61,6 & $\begin{array}{l}\text { 24) Antoninów (1999), 25) Glinojeck (2002), 26) Pionki (2019), } \\
\text { 27) Pruszków-Gąsin (2003), 28) Wieliszew (2016) }\end{array}$ \\
\hline Opolskie & 3 & 17,6 & $\begin{array}{l}\text { 29) Baków gm. Godków (2015), 30) Strzelce Opolskie (2000), } \\
\text { 31) Wołczyn (nie oddany / not in use) }\end{array}$ \\
\hline Podkarpackie & 4 & 25,0 & $\begin{array}{l}\text { 32) Jarosław (2019), 33) Lubaczów (2001), 34) Sanok (2000), } \\
\text { 35) Sarzyna (2001) }\end{array}$ \\
\hline Podlaskie & 2 & 12,1 & 36) Karakule (2010), 37) Zambrów (2000) \\
\hline Pomorskie & 2 & 6,5 & 38) Krzyżanowo (2008), 39) Łodzierz (2000) \\
\hline Śląskie & 9 & 28,5 & $\begin{array}{l}\text { 40) Częstochowa (2003), 41) Dąbrowa Górnicza (2000), } \\
\text { 42) Knurów (2006), 43) Miasteczko Śląskie (2012), 44) Mikołów } \\
\text { ul. Porazińskiej (2006), 45) Mikołów ul. Jesienna (2005), } \\
\text { 46) Nieboczowy (2016), 47) Świętochłowice-Piaśniki (2000), } \\
\text { 48) Żywiec (2005) }\end{array}$ \\
\hline Świętokrzyskie & 0 & - & - \\
\hline $\begin{array}{l}\text { Warmińsko- } \\
\text {-mazurskie }\end{array}$ & 5 & 42,0 & $\begin{array}{l}\text { 49) Bartosze (2014), 50) Biskupiec (2017), 51) Gołdap (2015), } \\
\text { 52) Iława (2005), 53) Lubawa (2004) }\end{array}$ \\
\hline Wielkopolskie & 2 & 7,5 & 54) Durzyn (nie oddany / not in use), 55) Luboń (2004) \\
\hline $\begin{array}{l}\text { Zachodnio- } \\
\text {-pomorskie }\end{array}$ & 8 & 125,4 & \begin{tabular}{|l} 
56) Barlinek Jaromierki (2010), 57) Gryfice (2001), 58) Koszalin \\
$(2018), 59)$ Stargard (2002), 60) Szczecin Cmentarz Zachodni \\
(2013), 61) Szczecinek (nie oddany / not in use), 62) Świdwin \\
(2000), 63) Świnoujście Przytór (2019) \\
\end{tabular} \\
\hline $\begin{array}{l}\text { ŁACZNIE } \\
\text { IN TOTAL }\end{array}$ & 63 & 496,2 & \\
\hline
\end{tabular}

Źródto: opracowanie własne na podstawie danych portali samorządowych.

Source: own elaboration based on local governments websites. 
Dokonano także analizy lokalizacji cmentarzy względem ciągłości systemów przyrodniczych, z ich podziałem na położone w lub poza tym systemem. Rejestrowano powiązanie w kategoriach: istnieje - nie istnieje (Komornicki 2013; Durecka 2017). Położenie cmentarzy względem obiektów religijnych objęło identyfikację budynków przeznaczonych do sprawowania kultu religijnego i czynności religijnych (tj.: świątynie, kaplice, cmentarze, krematoria - zgodnie z Polską Klasyfikacją Obiektów Budowlanych), jak również elementów kompozycji sakralnej (Swaryczewska 2008; Długozima 2014).

\section{Wyniki badań}

\section{Nowe cmentarze komunalne na tle zasobu sepulkralnego w Polsce}

Według GUS na dzień 31 lipca 2019 r. na obszarze Polski łącznie znajdowało się 16020 cmentarzy. Ich powierzchnia wynosiła 18293,59 ha. Status obiektu komunalnego miało 1920 cmentarzy, co stanowiło 12\% ogólnego zasobu cmentarnego. Należy podkreślić, iż większość cmentarzy komunalnych to obiekty, które w przeszłości były wyznaniowe, a w wyniku decyzji komunalizacyjnych w latach 70-90. XX w. były przekazywane samorządom i przekwalifikowane na komunalne (NIK 2016; Rogowska 2014). Względem 2018 r. zasób cmentarzy powiększył się o 76 obiektów o łącznej powierzchni 99,48 ha.

Niestety, nie ustalono typu oraz statusu cmentarzy oddanych do użytku w 2018 r., ponieważ GUS definiuje cmentarz jako miejsce przeznaczone do pochówku zmarłych (ludzi bądź zwierząt) bez względu na stan prawny, właściciela/zarządcę i wielkość terenu, na którego powierzchni znajdują się elementy zieleni. Przypuszcza się, że gros nowych cmentarzy stanowią grzebowiska (miejsca pochówku dla zwierząt). Myślińska (2018) w swoich badaniach zwraca uwagę, iż w Polsce dynamicznie wzrasta liczba takich cmentarzy, co wynika z przepisów prawa (obiekt może powstać jako inicjatywa prywatna, komercyjna) oraz ze społecznej potrzeby upamiętniania zwierząt domowych.

W latach 1999-2019 na terenie Polski założono 63 cmentarze komunalne o łącznej powierzchni 496,2 ha (tab. 3). Średnia powierzchnia nowego cmentarza komunalnego w pierwszym etapie inwestycji wynosi 3,6 ha. Docelowa powierzchnia oscyluje w granicach 7,5 ha. Spośród analizowanych obiektów trzy nie zostały dopuszczone do użytku (Durzyn, Szczecinek, Wołczyn). Część współczesnych cmentarzy jest położona na obszarach wiejskich (29\%), przy czym część tych obiektów zabezpiecza potrzeby grzebalne mieszkańców miast (np. cmentarz w Antoninowie dla Warszawy, cmentarz w Karakulach dla Białegostoku, cmentarz w Jaszkowie dla Legnicy) (ryc. 4). 


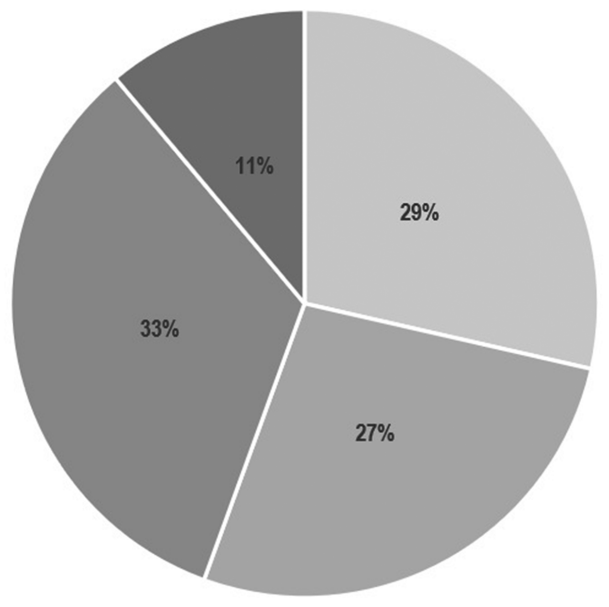

\footnotetext{
- wieś / village

- miasto małe $<20$ tys. mieszk. / small town, below 20 thou.

- miasto średnie 20 - 100 tys. mieszk. / medium sized town 20 - 100 thou. population

- miasto duże > 100 tys. / large town 100 thou. population and more
}

Ryc. 4. Klasyfikacja nowych cmentarzy komunalnych ze względu na status miejscowości Fig. 4. Classification of new communal cemeteries due to the status of settlement unit Źródto: opracowanie własne na podstawie danych BDL GUS.

Source: own elaboration based on Local Data Bank Statistics Poland.

Najliczniejszą grupę (60\% ogółu) stanowią cmentarze zakładane w małych i średnich miastach. W zestawieniu współczesnych cmentarzy komunalnych $11 \%$ przypada na miasta liczące powyżej 100000 mieszkańców, co w dużej mierze warunkowane jest urbanizacją, intensywnym zagospodarowaniem terenów i trudnością z pozyskaniem rozległych gruntów spełniających restrykcyjne kryteria sanitarno-epidemiologiczne (NIK 2016).

\section{Modele lokalizacji nowych cmentarzy komunalnych}

\section{Położenie cmentarzy względem systemu komunikacji}

Badając położenie cmentarzy względem systemu komunikacji, uwzględniono: liczbę wejść na teren obiektu, usytuowanie względem istniejącej sieci drogowej, obecność przystanków publicznego transportu zbiorowego oraz częstotliwość kursowania tego transportu. Na podstawie tych kryteriów wyznaczono trzy typy dostępności (tab. 4): 
Tab. 4. Dostępność komunikacyjna cmentarzy

Table 4. Transport accessibility of cemeteries

\begin{tabular}{|c|c|c|c|c|c|c|}
\hline \multirow[b]{2}{*}{$\begin{array}{l}\text { Dostępność } \\
\text { Accessibility }\end{array}$} & \multicolumn{2}{|c|}{ Przestrzenna / Spatial } & $\begin{array}{l}\text { Infrastrukturalna } \\
\text { Infrastructural }\end{array}$ & \multirow{2}{*}{\multicolumn{2}{|c|}{$[\%]$}} & \\
\hline & $\begin{array}{l}\text { liczba wejść } \\
\text { na teren } \\
\text { cmentarza } \\
\text { number of } \\
\text { entrances } \\
\text { to the } \\
\text { cemetery }\end{array}$ & $\begin{array}{l}\text { dostepp } \\
\text { do drogi } \\
\text { access to } \\
\text { a road }\end{array}$ & $\begin{array}{c}\text { przystanki publicznego } \\
\text { transportu } \\
\text { zbiorowego, } \\
\text { częstotliwość } \\
\text { kursowania } \\
\text { stops of public } \\
\text { transport, frequency }\end{array}$ & & & $\begin{array}{l}\text { cmentarzy } \\
\text { komunalnych } \\
\text { Examples } \\
\text { of communal } \\
\text { cemeteries }\end{array}$ \\
\hline \multirow{3}{*}{$\begin{array}{l}\text { Średnia } \\
\text { Medium }\end{array}$} & & & & \multirow{3}{*}{76,2} & 14,3 & $\begin{array}{l}\text { Bartosze, Borzy- } \\
\text { gniew, Durzyn, } \\
\text { Knurów, Rdziostów, } \\
\text { Starorypin Prywat- } \\
\text { ny, Wieliszew }\end{array}$ \\
\hline & & & $\pi$ & & 50,8 & $\begin{array}{l}\text { Barlinek, Bąków, } \\
\text { Biskupiec, Glino- } \\
\text { jeck, Gołdap, Nowa } \\
\text { Chełmża, Opoczno }\end{array}$ \\
\hline & & & & & 11,1 & $\begin{array}{l}\text { Brodnica, Gryfice, } \\
\text { Smolec, Stara Wieś }\end{array}$ \\
\hline $\begin{array}{l}\text { Dobra } \\
\text { Good }\end{array}$ & & & & & & $\begin{array}{l}\text { Iława, Nowy Targ, } \\
\text { Sanok, Strzelce } \\
\text { Opolskie }\end{array}$ \\
\hline \multirow{2}{*}{$\begin{array}{l}\text { Bardzo } \\
\text { dobra } \\
\text { Very good }\end{array}$} & & & & \multirow{2}{*}{11,1} & 4,8 & $\begin{array}{l}\text { Tarnów, Stargard, } \\
\text { Zielona Góra }\end{array}$ \\
\hline & & & $\frac{1}{6-1}$ & & 6,3 & $\begin{array}{l}\text { Antoninów, Często- } \\
\text { chowa, Świętochło- } \\
\text { wice }\end{array}$ \\
\hline
\end{tabular}


Dostępnością średnią charakteryzują się obiekty zlokalizowane przy drodze lokalnej, gdzie dojazd możliwy jest tylko samochodem prywatnym (cmentarz nie został włączony w system publicznego transportu zbiorowego), jak również cmentarze usytuowane przy głównych drogach prowadzących do centrum jednostek osadniczych, gdzie z uwagi na status miejscowości (wieś, małe miasto), strukturę funkcjonalno-przestrzenną oraz małe potoki pasażerskie (Dydkowski, Tomanek 2005) dojazd nań możliwy jest tylko samochodem prywatnym.

Dostępnością dobrą charakteryzują się cmentarze zlokalizowane przy drogach o statusie dróg wojewódzkich, włączone w system publicznego transportu zbiorowego (częstotliwość kursowania rzadziej niż co godzinę).

Dostępnością bardzo dobrą charakteryzują się cmentarze położone przy głównych drogach, włączone w system miejskiego transportu zbiorowego (więcej niż jedna linia publicznego transportu zbiorowego, częstotliwość kursowania częściej niż co godzinę).

\section{Położenie cmentarzy względem struktury funkcjonalno-przestrzennej}

Badając położenie cmentarzy komunalnych względem struktury przestrzennej, uwzględniono usytuowanie tych obiektów względem centrum i granic miejscowości, które obsługują. Ustalono, że współczesne cmentarze lokalizowane są:

1. Na terenach o niskiej gęstości zaludnienia, o charakterze wiejskim, w znacznym oddaleniu od centrum jednostki osadniczej (np.: cmentarz w Kobylanach ok. 2 km od centrum wsi, cmentarz komunalny w Bąkowie ok. 1 km od centrum wsi) bądź poza jej granicami (np.: cmentarz komunalny w Jaszkowie leży ok. 3 km od granic Legnicy, cmentarz komunalny w Karakulach ok. 4 km od granic Białegostoku, Cmentarz Komunalny Południowy w Antoninowie oddalony jest zaś o ok. 15 km od granic m.st. Warszawy);

2. Na terenach o umiarkowanej gęstości zaludnienia, o charakterze podmiejskim, w umiarkowanej odległości od centrum jednostki osadniczej (np.: Pruszków, Lubaczów, Brodnica, Iława, Gołdap).

Badanie ziarnistości pozwoliło wyodrębnić trzy modele lokalizacji cmentarzy komunalnych:

1. Cmentarze położone na terenach o strukturze gruboziarnistej, w otoczeniu wielkogabarytowych budynków o charakterze przemysłowym, magazynowym, logistycznym (np.: Pruszków, Żywiec, Lubawa, Strzegom, Luboń) (ryc. 5A);

2. Cmentarze położone na terenach niezagospodarowanych, w sąsiedztwie ekstensywnej zabudowy o drobnej strukturze (głównie zabudowa mieszkaniowa jednorodzinna oraz zagrodowa) (np.: Bartosze, Barlinek, Glinojeck, Antoninów, Grudziądz, Gryfice, Krzyżanowo, Łuków, Strzelce Opolskie) (ryc. 5B); 
3. Cmentarze położone w tzw. klinie, czyli strefie przejściowej między zabudową o strukturze drobno- i gruboziarnistej (np.: Gołdap, Biskupiec, Dąbrowa Górnicza, Durzyn, Iława) (ryc. 5C).

Usytuowanie w strukturze przestrzennej determinuje postrzegalność cmentarzy komunalnych w przestrzeni. Postrzegalność ocenianych obiektów określono jako średnią (cmentarze widoczne z różnych, ale nie wszystkich stron), słabą (cmentarze widoczne z niektórych stron) lub bardzo słabą (cmentarze praktycznie niewidoczne, ewentualnie z najbliższej okolicy, z jednej strony). Postrzegalność cmentarzy jest ściśle powiązana z dostępnością komunikacyjną obiektu oraz sposobem zagospodarowania strefy ochronnej. Cmentarze zlokalizowane w otoczeniu obiektów wielkogabarytowych są trudne do zidentyfikowania.

Badając położenie cmentarzy komunalnych względem struktury funkcjonalno-przestrzennej, zidentyfikowano następujące dominujące funkcje terenów i zabudowy w strefie ochrony sanitarnej tych obiektów (ryc. 6):

1. Otwarte nieurządzone (31\% ogółu) (np.: Częstochowa, Gryfice, Jaszków, Kobylany, Międzyrzec Podlaski, Opoczno, Wieliszew);

2. Mieszkaniowe z zabudową jednorodzinną, zagrodową (14,5\%) (np.: Stara Wieś, Smolec, Nowa Chełmża, Lubaczów, Biskupiec, Barlinek);

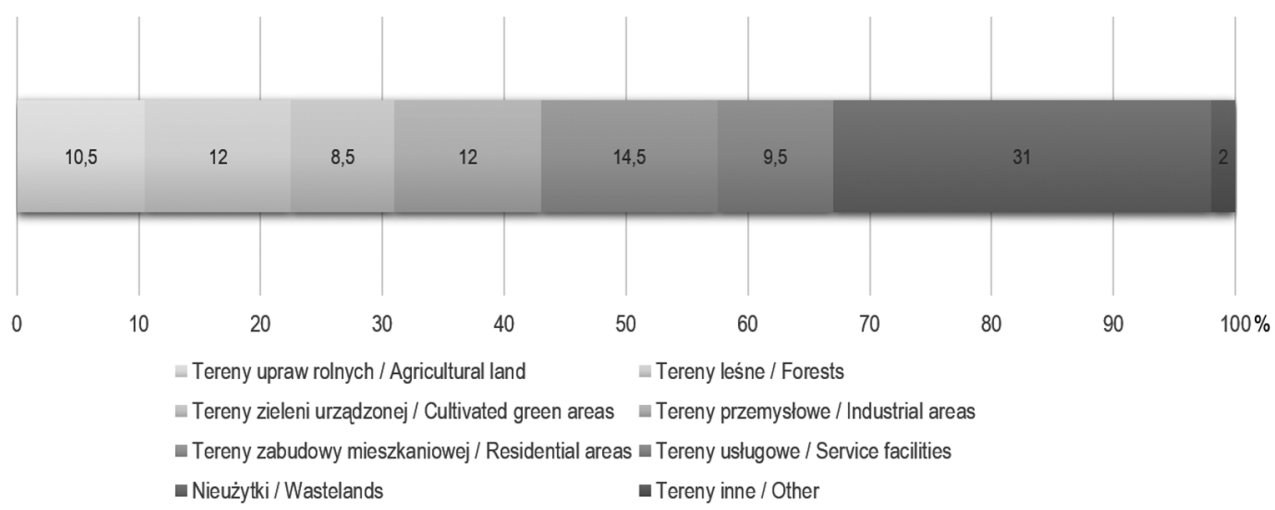

Ryc. 6. Struktura użytkowania terenów w strefie ochronnej nowych cmentarzy komunalnych Fig. 6. Land use structure within the protection zone of new communal cemeteries Źródto: opracowanie własne na podstawie danych BDOT10k oraz OSM.

Source: own elaboration based on BDOT10k and OSM. 

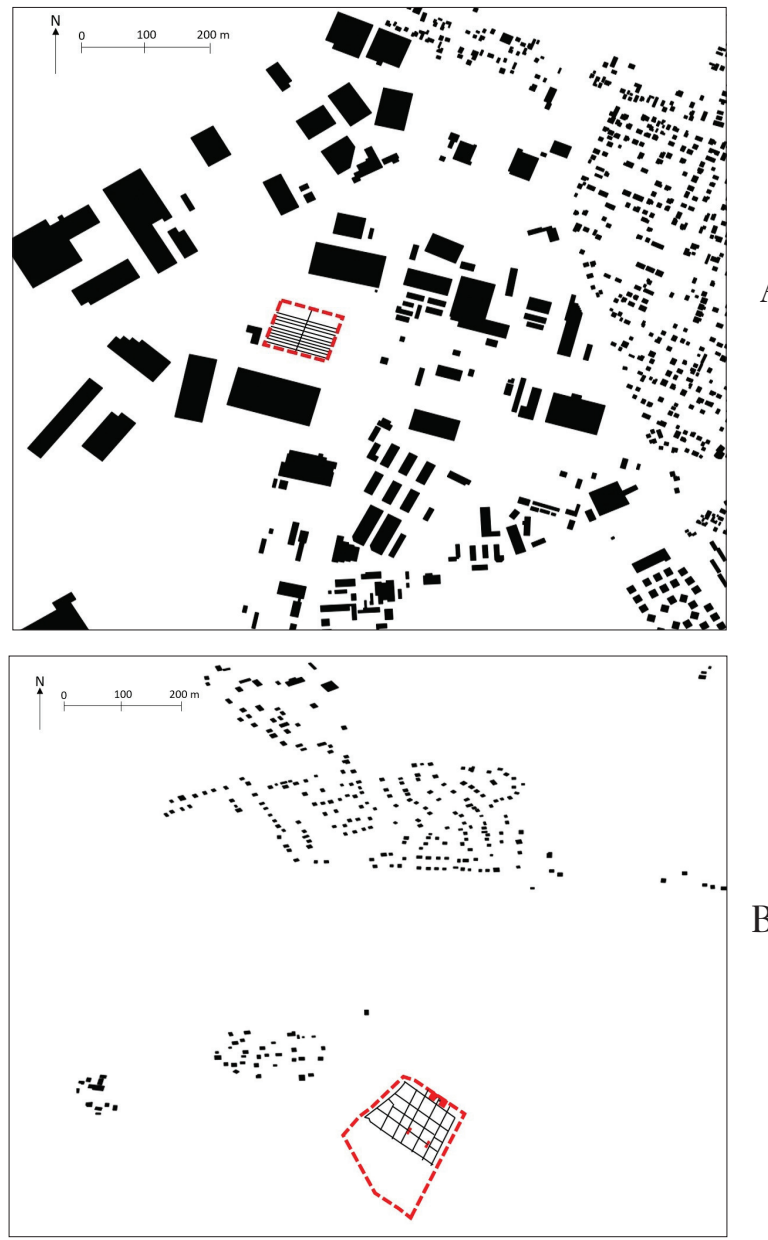

B

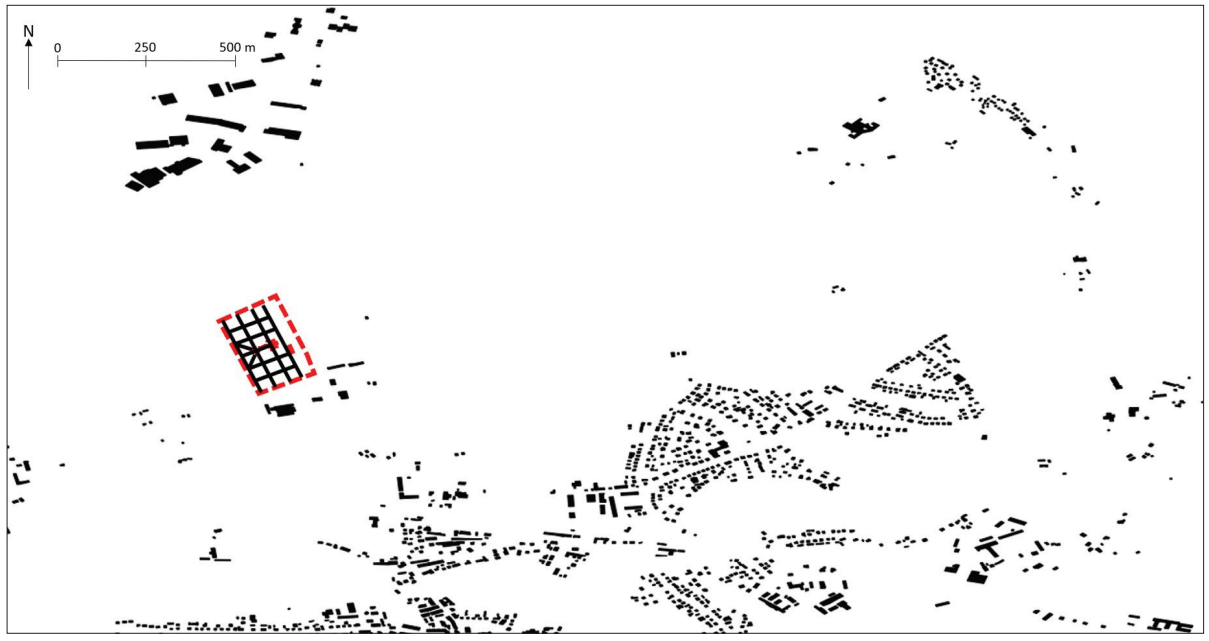

Ryc. 5. Położenie cmentarzy komunalnych w strukturze przestrzennej jednostki osadniczej: Pruszkowa (A), Bartoszyc (B), Gołdapi (C)

Fig. 5. Location of communal cemeteries in the spatial structure of a settlement unit: Pruszków (A), Bartoszyce (B), Gołdap (C)

Źródto: opracowanie własne na podstawie danych BDOT10k oraz OSM.

Source: own elaboration based on BDOT10k and OSM. 
3. Przemysłowe z obiektami produkcyjnymi, składami, magazynami, kamieniołomami, żwirowniami i piaskowniami (12\%) (np.: Żeleźnik, Strzegom, Pruszków, Świnoujście Przytór, Żywiec);

4. Leśne (12\%) (np.: Antoninów, Jelenia Góra Cieplice, Karakule, Pionki, Rdziostów, Zielona Góra);

5. Rolne (10,5\%) (np.: Rejowiec, Durzyn, Nowa Chełmża, Starorypin Prywatny);

6. Usługowe (9,5\%) (np.: Gołdap, Luboń, Nowy Targ);

7. Zieleni urządzonej, tj.: ogrody działkowe, cmentarze, parki $(8,5 \%)$ (np. Opole Lubelskie, Wieluń, Tarnów).

Analiza zagospodarowania otoczenia cmentarzy komunalnych w ich strefie sanitarnej 150 m uwidoczniła szereg uciążliwości (tab. 5).

Tab. 5. Zestawienie uciążliwości zidentyfikowanych w strefie ochronnej 150 m współczesnych cmentarzy komunalnych

Table 5. Summary of the nuisances identified within the $150-\mathrm{m}$ protection zone of contemporary communal cemeteries

\begin{tabular}{|l|l|}
\hline \multicolumn{1}{|c|}{\begin{tabular}{c} 
Rodzaj uciążliwości w strefie \\
sanitarnej $150 \mathrm{~m}$ \\
\multicolumn{1}{|c|}{$\begin{array}{c}\text { Nuisance in the } 150 \mathrm{~m} \text { cemetery } \\
\text { sanitary zone }\end{array}$}
\end{tabular}} & \multicolumn{1}{c|}{$\begin{array}{c}\text { Przykłady cmentarzy komunalnych } \\
\text { Examples of communal cemeteries }\end{array}$} \\
\hline Obwodnica / Ring road & Dąbrowa Górnicza, Szczecinek \\
\hline $\begin{array}{l}\text { Linia kolejowa / Railway } \\
\text { Bartosze, Borzygniew, Dąbrowa Górnicza, Durzyn, Iława, Jarosław, Kosza- } \\
\text { lin (Koszalińska Linia Wąskotorowa), Knurów, Luboń, Rdziostów, Szczecin } \\
\text { (węzeł kolejowy), Szczecinek, Wieliszew }\end{array}$ \\
\hline $\begin{array}{l}\text { Linia elektroenergetyczna 110 kV, } \\
\text { kV, 220 kV / Overhead power line 110 }\end{array}$ & $\begin{array}{l}\text { Antoninów, Durzyn, Łodzierz, Mikołów ul. Jesienna, Opoczno, Rdziostów, } \\
\text { Sarzyna, Stargard, Wieliszew, Zambrów }\end{array}$ \\
\hline $\begin{array}{l}\text { Teren produkcyjny (hałas) } \\
\text { Production facilitiy (noise) }\end{array}$ & Dąbrowa Górnicza, Lubawa, Pruszków Gąsin, Żywiec \\
\hline $\begin{array}{l}\text { Stacja transformatorowa } \\
\text { Transformer station }\end{array}$ & Nowe Nieboczowy, Świnoujście Przytór \\
\hline $\begin{array}{l}\text { Oczyszczalnia ścieków } \\
\text { Waste water treatment plant }\end{array}$ & Knurów (Centralna Oczyszczalnia Ścieków), Łodzierz \\
\hline $\begin{array}{l}\text { Miejsce recyklingu odpadów } \\
\text { Waste recycling site }\end{array}$ & Świnoujście Przytór \\
\hline $\begin{array}{l}\text { Teren wojskowy / Military area } \\
\text { Brodnica }\end{array}$ \\
\hline
\end{tabular}




\section{Położenie cmentarzy względem systemu przyrodniczego}

Badając położenie cmentarzy względem ciągłości systemów przyrodniczych, rejestrowano powiązanie w kategoriach: istnieje - nie istnieje, co stanowiło podstawę do wypracowania pięciu modeli lokalizacji (ryc. 7). Cztery modele odnoszą się do cmentarzy położonych w ciągłym systemie przyrodniczym (modele nr 1-4), jeden model odnosi się do cmentarzy położonych poza ciągłym systemem przyrodniczym (model nr 5):

1. Cmentarze położone pośród terenów otwartych, mogące stanowić enklawę zieleni wysokiej (pod warunkiem, że w ich zagospodarowaniu uwzględniono drzewostan), wzbogacając krajobraz jednostki osadniczej (np.: Bartosze, Bąków, Nowy Targ, Strzelce Opolskie, Zambrów); najczęściej jednak współczesne cmentarze są niemal pozbawione drzew (np.: Borzygniew, Krzyżanowo, Międzyrzec Podlaski, Nowogrodziec, Opoczno, Smolec, Starorypin Prywatny) (ryc. 7A);

2. Cmentarze położone pośród terenów otwartych, w sąsiedztwie lasów (np.: Glinojeck, Jaszków, Jelenia Góra, Karakule, Knurów, Grudziądz-Kobylanka, Łodzierz, Łuków, Mikołów ul. Jesienna, Sarzyna), w tym terenów leśnych objętych ochroną prawną (np. cmentarz w Antoninowie sąsiaduje z Warszawskim Obszarem Chronionego Krajobrazu, cmentarz w Barlinku zaś z Barlinecko-Głogowskim Parkiem Krajobrazowym) (ryc. 7B);

3. Cmentarze położone w sąsiedztwie cieków i terenów z zielenią nadwodną (np.: Brodnica - rezerwat rzeki Drwęca, Nowy Targ - rzeka Biały Dunajec, Sanok Potok Płowiecki, Stara Wieś - rzeka Świnka, Rdziostów - rzeka Biczynianka, Strzegom - rzeka Strzegomka, Żeleźnik - rzeka Krynka) (ryc. 7C);

4. Cmentarze sytuowane $\mathrm{w}$ sąsiedztwie historycznych cmentarzy oraz innych terenów zieleni urządzonej, np. ogrodów działkowych, zieleni towarzyszącej fortyfikacjom (np.: Częstochowa, Gołdap, Kobylany, Jarosław, Opole Lubelskie, Pionki, Stargard, Wieluń, Zielona Góra). Ponadto, w kilku przypadkach zauważono, że powiązanie cmentarzy komunalnych z systemem przyrodniczym osiągane jest przez projektowanie alei i szpalerów drzew (np. Nowa Chełmża, Gryfice) (ryc. 7D). Ewenementem jest cmentarz komunalny w Luboniu, którego lokalizacja została wpisana w korytarz ekologiczny rzeki Warty o znaczeniu regionalnym (choć wartość tego terenu obniżają zakłady produkcyjne) (Studium uwarunkowań ... 2008);

5. Cmentarze położone pośród terenów zabudowanych, zainwestowanych lub planowanych do zabudowy (zgodnie z zapisami dokumentów planistycznych), w separacji względem innych terenów zieleni (np.: Dąbrowa Górnicza, Lubawa, Pruszków-Gąsin, Świnoujście, Żywiec) (ryc. 7E). 


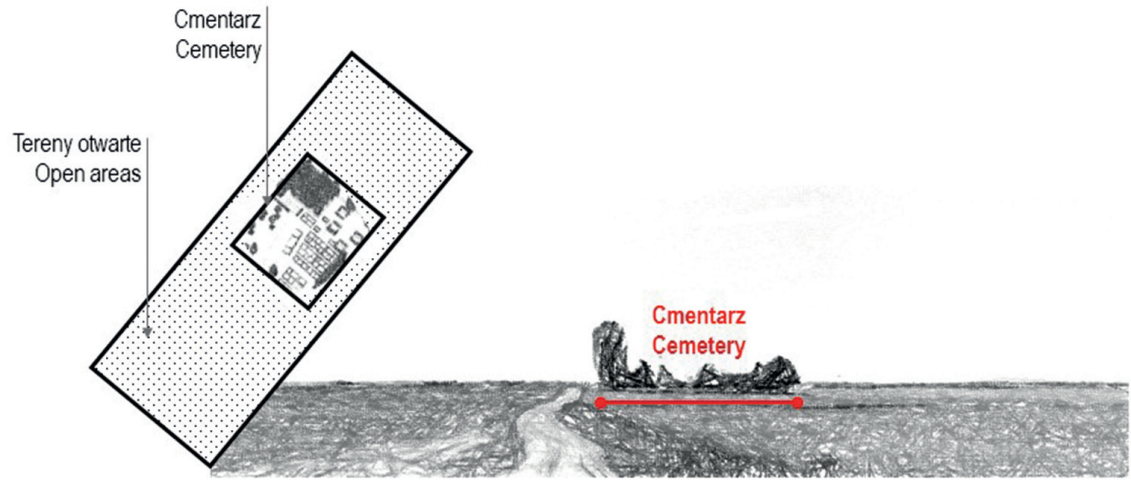

Ryc. 7A. Cmentarz położony w otoczeniu terenów otwartych

Fig. 7A. Cemetery surrounded by open areas

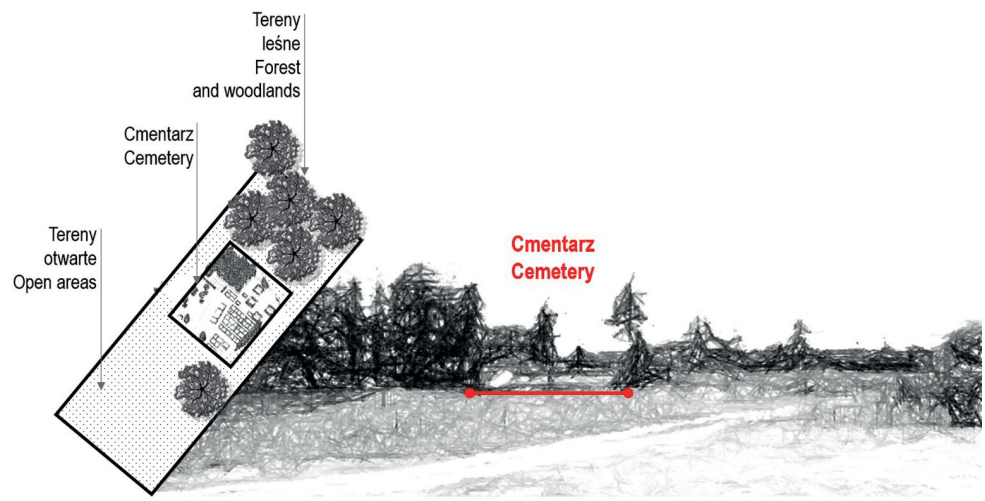

Ryc. 7B. Cmentarz położony w systemie terenów otwartych i leśnych

Fig. 7B. Cemetery surrounded by a system of open areas and forests

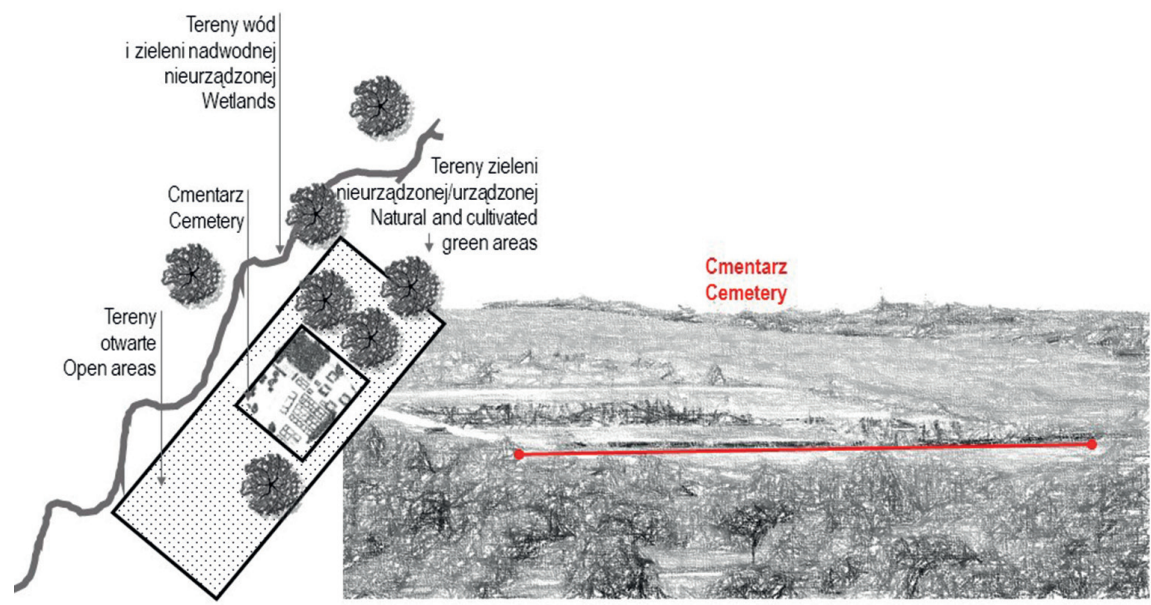

Ryc. 7C. Cmentarz położony w sąsiedztwie cieków i terenów z zielenią nadwodną

Fig. 7C. Cemetery situated in the vicinity of watercourses, wetlands and natural green areas 




Cmentarz / Cemetery

Ryc. 7D. Cmentarz wpisany w kontekst cmentarza historycznego i zieleni urządzonej

Fig. 7D. Cemetery set in a context of historic cemetery and cultivated green areas

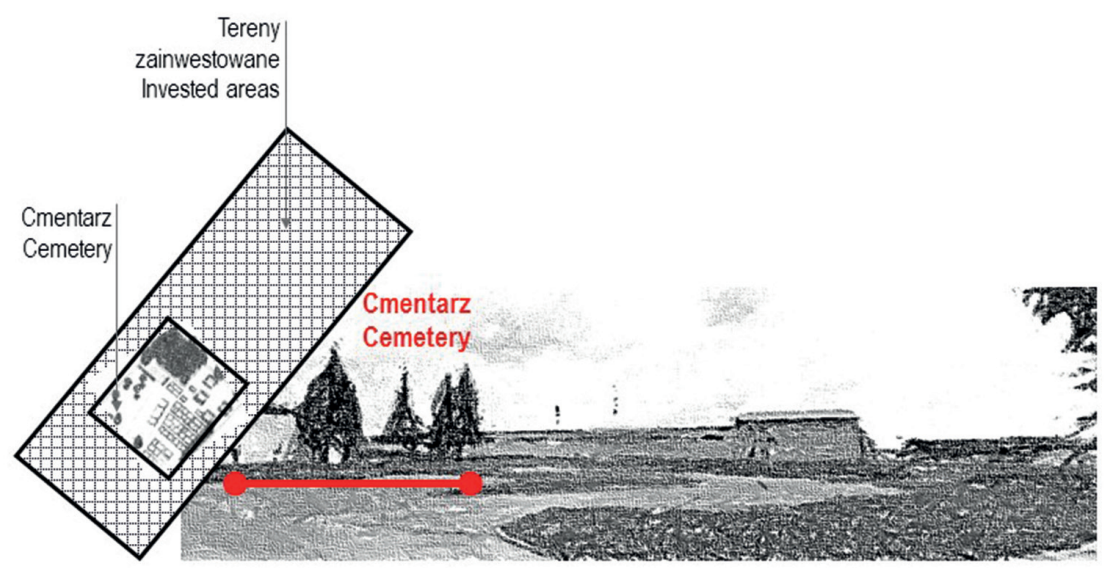

Ryc. 7E. Cmentarz poza systemem przyrodniczym, w otoczeniu terenów zainwestowanych Fig. 7E. Cemetery outside of the natural system, surrounded by invested area 


\section{Położenie cmentarzy względem obiektów sacrum}

Badanie położenia cmentarzy względem obiektów sacrum objęło identyfikację w strefie ochronnej budynków przeznaczonych do sprawowania kultu religijnego i czynności religijnych (tj.: świątynie, kaplice, cmentarze, krematoria - zgodnie z Polską Klasyfikacją Obiektów Budowlanych), jak również elementów kompozycji sakralnej. Zauważono, że większość współczesnych cmentarzy komunalnych zbudowano w otoczeniu terenów, które pełnią aktualnie lub pełniły w przeszłości funkcje grzebalne. W bezpośrednim sąsiedztwie czynnych, ale zapełnionych już cmentarzy komunalnych zrealizowano nowe inwestycje o tożsamym programie użytkowania i statusie (np.: Gołdap, Jarosław, Koszalin, Stargard, Szczecinek, Świnoujście Przytór, Zielona Góra). W sąsiedztwie cmentarzy parafialnych założono obiekty komunalne w: Brodnicy, Częstochowie, Opolu Lubelskim, Pionkach, Tarnowie i Wieluniu. W 150-metrowej strefie ochronnej cmentarzy komunalnych w Nowym Targu, Wołczynie, Żywcu znajdują się cmentarze żydowskie, w Bartoszach cmentarz ewangelicki, w Rdziostowie zaś miejsce straceń i cmentarz z okresu II wojny Światowej. W Mikołowie (ul. Porazińskiej) i Świętochłowicach cmentarze komunalne założono w bezpośrednim sąsiedztwie kościoła, co stanowi nawiązanie do utrwalonego przez historię i tradycję chrześcijańską związku świątyni z przestrzenią grzebalną (Długozima 2014). W Biskupcu, Borzygniewie, Nowogrodźcu, Rejowcu, Strzelcach Opolskich, Zambrowie symboliczną łączność obiektów sacrum wyraża powiązanie widokowe. W Karakulach, Nowej Chełmży i Pruszkowie budowa cmentarza komunalnego stała się impulsem do uruchomienia krematorium.

\section{Synteza badań. Lokalizacja współczesnych cmentarzy komunalnych}

Analiza współczesnych cmentarzy komunalnych w aspekcie ich lokalizacji pozwoliła wygenerować cechy charakterystyczne 63 obiektów (tab. 6-8).

Wszystkie objęte badaniami cmentarze komunalne (63) zostały ocenione pod kątem ich położenia. Kryteria oceny wraz z cechami prezentuje tab. 6, a w tab. 7 przyporządkowano je obiektom badawczym (tab. 7-8, kolejność obiektów jest zgodna z ich prezentacją w tab. 3). 
Tab. 6. Zestawienie cech współczesnych cmentarzy komunalnych w aspekcie lokalizacji Table 6. Summary of contemporary communal cemeteries features in the aspect of their location

\begin{tabular}{|c|c|c|}
\hline \multicolumn{2}{|c|}{$\begin{array}{l}\text { Ocena lokalizacji cmentarza } \\
\text { Assessment of cemetery } \\
\text { location }\end{array}$} & Cechy charakterystyczne cmentarza / Characteristic features of cemetery \\
\hline \multirow{3}{*}{$\begin{array}{l}\text { Względem systemu } \\
\text { komunikacji } \\
\text { In relation to trans- } \\
\text { port system }\end{array}$} & \multirow{3}{*}{1} & $\begin{array}{l}\text { Dostępność średnia (dojazd tylko samochodem prywatnym) / Medium accessibility } \\
\text { (only private transport) }\end{array}$ \\
\hline & & $\begin{array}{l}\text { Dostępność dobra (dojazd zarówno samochodem prywatnym, jak również } \\
\text { środkiem publicznego transportu zbiorowego) / Good accessibility (access to both } \\
\text { private and public transport) }\end{array}$ \\
\hline & & $\begin{array}{l}\text { Dostępność bardzo dobra (dojazd zarówno samochodem prywatnym, jak również } \\
\text { środkiem publicznego transportu zbiorowego o dużej częstotliwości kursowania) } \\
\text { Very good accessibility (access to both private and public transport with high } \\
\text { frequency) }\end{array}$ \\
\hline \multirow{5}{*}{$\begin{array}{l}\text { Względem struktury } \\
\text { przestrzennej } \\
\text { In relation to spatial } \\
\text { structure }\end{array}$} & \multirow{2}{*}{2} & $\begin{array}{l}\text { Cmentarz położony peryferyjnie względem centrum jednostki osadniczej } \\
\text { (zlokalizowany na terenach o niskiej gęstości zaludnienia, o charakterze wiejskim) } \\
\text { Cemetery located peripherally in relation to the center of settlement unit } \\
\text { (located in low-density, rural clusters) }\end{array}$ \\
\hline & & $\begin{array}{l}\text { Cmentarz położony w umiarkowanej odległości od centrum jednostki osadniczej } \\
\text { (zlokalizowany na terenach o umiarkowanej gęstości zaludnienia, o charakterze } \\
\text { podmiejskim) / Cemetery located moderate distance from the center of settlement } \\
\text { unit (located in clusters with moderate density of suburban population) }\end{array}$ \\
\hline & \multirow{3}{*}{3} & $\begin{array}{l}\text { Cmentarz położony na terenie charakteryzującym się zabudową o strukturze } \\
\text { drobnoziarnistej / Cemetery located on area with fine-grained structure }\end{array}$ \\
\hline & & $\begin{array}{l}\text { Cmentarz położony na terenie charakteryzującym się zabudową o strukturze } \\
\text { gruboziarnistej / Cemetery located on area with large scale buildings }\end{array}$ \\
\hline & & $\begin{array}{l}\text { Cmentarz położony na terenie charakteryzującym się zabudową o strukturze } \\
\text { mieszanej / Cemetery located on area with mixed structure buildings }\end{array}$ \\
\hline \multirow{3}{*}{$\begin{array}{l}\text { Względem funkcji } \\
\text { terenu i zabudowy } \\
\text { In relation to } \\
\text { area and building } \\
\text { functions }\end{array}$} & \multirow{3}{*}{4} & $\begin{array}{l}\text { Cmentarz położony na terenach niezagospodarowanych / Cemetery located } \\
\text { in undeveloped areas }\end{array}$ \\
\hline & & $\begin{array}{l}\text { Cmentarz położony na terenie o monofunkcyjnym programie użytkowania, głównie } \\
\text { tereny produkcyjne / Cemetery is located on a site with monofunctional program, } \\
\text { mainly production areas }\end{array}$ \\
\hline & & $\begin{array}{l}\text { Cmentarz położony na terenie o rozbudowanym programie użytkowym / Cemetery } \\
\text { is located on a site with multifunctional program }\end{array}$ \\
\hline \multirow{2}{*}{$\begin{array}{l}\text { Względem systemu } \\
\text { przyrodniczego } \\
\text { In relation to natural } \\
\text { system }\end{array}$} & \multirow{2}{*}{5} & $\begin{array}{l}\text { Cmentarz poza ciagłym systemem przyrodniczym / There is no connection between } \\
\text { cemetery and natural system }\end{array}$ \\
\hline & & $\begin{array}{l}\text { Cmentarz w ciągłym systemie przyrodniczym / Cemetery is included in the natural } \\
\text { system }\end{array}$ \\
\hline \multirow{3}{*}{$\begin{array}{l}\text { Względem obiektów } \\
\text { religijnych } \\
\text { In relation to religio- } \\
\text { us facilities }\end{array}$} & \multirow{3}{*}{6} & $\begin{array}{l}\text { Brak obiektów religijnych w sąsiedztwie cmentarza / Lack of religious facilities } \\
\text { in the cemetery vicinity }\end{array}$ \\
\hline & & $\begin{array}{l}\text { Obiekty religijne poza strefą ochronną cmentarza, ale powiązane z nim widokowo, } \\
\text { kompozycyjnie / Religious facilities outside the sanitary zone of the cemetery, but } \\
\text { connected by views, composition }\end{array}$ \\
\hline & & $\begin{array}{l}\text { Obecność obiektów religijnych w bezpośrednim sąsiedztwie cmentarza / Religious } \\
\text { facilities in the vicinity of cemetery }\end{array}$ \\
\hline
\end{tabular}


Tab. 7. Ocena lokalizacji współczesnych cmentarzy komunalnych - podsumowanie. Część 1 (cmentarze nr 1-36)

Table 7. Assessment of location of contemporary communal cemeteries - summary. Part 1 (cemeteries no. 1-36)

\begin{tabular}{|c|c|c|c|c|c|c|c|c|c|c|c|c|c|c|c|c|}
\hline \multicolumn{3}{|c|}{1} & \multicolumn{3}{|c|}{2} & \multicolumn{3}{|c|}{3} & \multicolumn{3}{|c|}{4} & \multicolumn{3}{|c|}{5} & \multicolumn{2}{|c|}{6} \\
\hline 1 & 2 & 3 & 1 & 2 & 3 & 1 & 2 & 3 & 1 & 2 & 3 & 1 & 2 & 3 & 1 & 2 \\
\hline 4 & 5 & 6 & 4 & 5 & 6 & 4 & 5 & 6 & 4 & 5 & 6 & 4 & 5 & 6 & 4 & 5 \\
\hline \multicolumn{3}{|c|}{7} & \multicolumn{3}{|c|}{8} & \multicolumn{3}{|c|}{9} & \multicolumn{3}{|c|}{10} & \multicolumn{3}{|c|}{11} & \multicolumn{2}{|c|}{12} \\
\hline 1 & 2 & 3 & 1 & 2 & 3 & 1 & 2 & 3 & 1 & 2 & 3 & 1 & 2 & 3 & 1 & 2 \\
\hline 4 & 5 & 6 & 4 & 5 & 6 & 4 & 5 & 6 & 4 & 5 & 6 & 4 & 5 & 6 & 4 & 5 \\
\hline \multicolumn{3}{|c|}{13} & \multicolumn{3}{|c|}{14} & \multicolumn{3}{|c|}{15} & \multicolumn{3}{|c|}{16} & \multicolumn{3}{|c|}{17} & \multicolumn{2}{|c|}{18} \\
\hline 1 & 2 & 3 & 1 & 2 & 3 & 1 & 2 & 3 & 1 & 2 & 3 & 1 & 2 & 3 & 1 & 2 \\
\hline 4 & 5 & 6 & 4 & 5 & 6 & 4 & 5 & 6 & 4 & 5 & 6 & 4 & 5 & 6 & 4 & 5 \\
\hline \multicolumn{3}{|c|}{19} & \multicolumn{3}{|c|}{20} & \multicolumn{3}{|c|}{21} & \multicolumn{3}{|c|}{22} & \multicolumn{3}{|c|}{23} & \multicolumn{2}{|c|}{24} \\
\hline 1 & 2 & 3 & 1 & 2 & 3 & 1 & 2 & 3 & 1 & 2 & 3 & 1 & 2 & 3 & 1 & 2 \\
\hline 4 & 5 & 6 & 4 & 5 & 6 & 4 & 5 & 6 & 4 & 5 & 6 & 4 & 5 & 6 & 4 & 5 \\
\hline \multicolumn{3}{|c|}{25} & \multicolumn{3}{|c|}{26} & \multicolumn{3}{|c|}{27} & \multicolumn{3}{|c|}{28} & \multicolumn{3}{|c|}{29} & \multicolumn{2}{|c|}{30} \\
\hline 1 & 2 & 3 & 1 & 2 & 3 & 1 & 2 & 3 & 1 & 2 & 3 & 1 & 2 & 3 & 1 & 2 \\
\hline 4 & 5 & 6 & 4 & 5 & 6 & 4 & 5 & 6 & 4 & 5 & 6 & 4 & 5 & 6 & 4 & 5 \\
\hline \multicolumn{3}{|c|}{31} & \multicolumn{3}{|c|}{32} & & 33 & & & 34 & & & 35 & & & \\
\hline 1 & 2 & 3 & 1 & 2 & 3 & 1 & 2 & 3 & 1 & 2 & 3 & 1 & 2 & 3 & 1 & 2 \\
\hline 4 & 5 & 6 & 4 & 5 & 6 & 4 & 5 & 6 & 4 & 5 & 6 & 4 & 5 & 6 & 4 & 5 \\
\hline
\end{tabular}

\section{Podsumowanie}

Raport NIK (2016) wskazuje na niepokojące zjawisko: w ostatniej dekadzie niewiele samorządów zdecydowało się na budowę cmentarzy komunalnych. W raporcie brakuje precyzyjnych danych, ponieważ w Polsce nie prowadzi się statystyk odnośnie do liczby nowo budowanych nekropolii. Przeszkodą w realizacji inwestycji cmentarnych jest brak odpowiednich terenów spełniających warunki określone w przepisach prawnych. Z uwagi na dominację pochówków tradycyjnych (inhumacja) cmentarze w Polsce są inwestycjami wielkopowierzchniowymi, co w połączeniu z restrykcyjnymi kryteriami sanitarno-epidemiologicznymi powoduje, że współczesne nekropolie zakładane są na terenach, które nie kwalifikują się na inne inwestycje ze względu na uciążliwości (tab. 5). 
Tab. 8. Ocena lokalizacji współczesnych cmentarzy komunalnych - podsumowanie. Część 2 (cmentarze nr 37-63)

Table 8 . Assessment of location of contemporary communal cemeteries - summary. Part 2. (cemeteries no. 37-63)

\begin{tabular}{|c|c|c|c|c|c|c|c|c|c|c|c|c|c|c|c|c|}
\hline \multicolumn{3}{|c|}{37} & \multicolumn{3}{|c|}{38} & \multicolumn{3}{|c|}{39} & \multicolumn{3}{|c|}{40} & \multicolumn{3}{|c|}{41} & \multicolumn{2}{|c|}{42} \\
\hline 1 & 2 & 3 & 1 & 2 & 3 & 1 & 2 & 3 & 1 & 2 & 3 & 1 & 2 & 3 & 1 & 2 \\
\hline 4 & 5 & 6 & 4 & 5 & 6 & 4 & 5 & 6 & 4 & 5 & 6 & 4 & 5 & 6 & 4 & 5 \\
\hline \multicolumn{3}{|c|}{43} & \multicolumn{3}{|c|}{44} & \multicolumn{3}{|c|}{45} & \multicolumn{3}{|c|}{46} & \multicolumn{3}{|c|}{47} & \multicolumn{2}{|c|}{48} \\
\hline 1 & 2 & 3 & 1 & 2 & 3 & 1 & 2 & 3 & 1 & 2 & 3 & 1 & 2 & 3 & 1 & 2 \\
\hline 4 & 5 & 6 & 4 & 5 & 6 & 4 & 5 & 6 & 4 & 5 & 6 & 4 & 5 & 6 & 4 & 5 \\
\hline \multicolumn{3}{|c|}{49} & \multicolumn{3}{|c|}{50} & \multicolumn{3}{|c|}{51} & \multicolumn{3}{|c|}{52} & \multicolumn{3}{|c|}{53} & \multicolumn{2}{|c|}{54} \\
\hline 1 & 2 & 3 & 1 & 2 & 3 & 1 & 2 & 3 & 1 & 2 & 3 & 1 & 2 & 3 & 1 & 2 \\
\hline 4 & 5 & 6 & 4 & 5 & 6 & 4 & 5 & 6 & 4 & 5 & 6 & 4 & 5 & 6 & 4 & 5 \\
\hline \multicolumn{3}{|c|}{55} & \multicolumn{3}{|c|}{56} & \multicolumn{3}{|c|}{57} & \multicolumn{3}{|c|}{58} & \multicolumn{3}{|c|}{59} & \multicolumn{2}{|c|}{60} \\
\hline 1 & 2 & 3 & 1 & 2 & 3 & 1 & 2 & 3 & 1 & 2 & 3 & 1 & 2 & 3 & 1 & 2 \\
\hline 4 & 5 & 6 & 4 & 5 & 6 & 4 & 5 & 6 & 4 & 5 & 6 & 4 & 5 & 6 & 4 & 5 \\
\hline \multicolumn{3}{|c|}{61} & \multicolumn{3}{|c|}{62} & \multicolumn{3}{|c|}{63} & & & & & & & & \\
\hline 1 & 2 & 3 & 1 & 2 & 3 & 1 & 2 & 3 & & & & & & & & \\
\hline 4 & 5 & 6 & 4 & 5 & 6 & 4 & 5 & 6 & & & & & & & & \\
\hline
\end{tabular}

Dostępność komunikacyjna współczesnego cmentarza jest zredukowana. Najczęściej można nań wejść, korzystając z jednego dostępnego wejścia. Wpisanie w system komunikacyjny polega na zaprojektowaniu drogi dojazdowej, której celem jest właśnie cmentarz. Takie same wnioski sformułował Moonen (2009), badając lokalizację miejskich cmentarzy w Holandii. Lokalizowanie cmentarzy na terenach niezagospodarowanych sprawia, że są trudniej dostępne (wysokie koszty infrastruktury komunikacyjnej powodują, że w pierwszej fazie funkcjonowania obiektu dojazd możliwy jest tylko transportem prywatnym). Thomas (1991), badając lokalizację współczesnych cmentarzy na świecie, skonstatował, że świadczy to o ukrywaniu śmierci i tabuizacji tego tematu w społeczeństwie. Z uwagi na uwarunkowania społeczno-kulturowe (wzrastająca sekularyzacja, naśladownictwo rozwiązań z Zachodu) należy wnioskować, że udział cmentarzy komunalnych wśród nowych inwestycji grzebalnych będzie wzrastać, pod warunkiem, że uda się wypracować zasady ich lokalizacji. Synergia uwarunkowań przyrodniczych (położenie cmentarza względem systemu przyrodniczego), przestrzenno-funkcjonalnych (położenie cmentarza względem struktury przestrzennej oraz funkcji terenu i zabudowy) oraz społecznych 
(położenie cmentarza względem systemu komunikacyjnego oraz obiektów religijnych) przyczyni się do optymalizacji umiejscawiania cmentarzy. Aby to osiągnąć, niezbędna jest aktualizacja anachronicznej Ustawy o cmentar:ach $i$ chowaniu zmartych (Dz. U. 1959, Nr 11, poz. 62). Wniosek ten koresponduje z rekomendacjami NIK (2016) opracowanymi po kontroli wytypowanych cmentarzy komunalnych.

Aby cmentarz funkcjonował jako przestrzeń multifunkcjonalna, a takie role nakładają na obiekt zarówno przepisy prawa, jak i tradycja, niezbędne jest podjęcie działań dążących do integracji cmentarzy ze strukturami funkcjonalno-przestrzennymi jednostek osadniczych. Planując położenie cmentarza, należy odnosić się do koncepcji dobra wspólnego. Wszak cmentarze są przedmiotem troski zarówno zarządców, właścicieli, jak i społeczności lokalnych. Wszystkim tym podmiotom zależy na optymalnej lokalizacji tych obiektów.

\section{Podziękowania}

Niniejszy artykuł powstał w wyniku realizacji projektu badawczego pn.: „Wpisywanie cmentarzy w istniejące układy urbanistyczne i ruralistyczne w Polsce w aspekcie ładu przestrzennego na tle współczesnej europejskiej przestrzeni sepulkralnej”, o nr. 2016/23/D/HS4/03043, finansowanego ze środków Narodowego Centrum Nauki.

Składam serdeczne podziękowania Redaktorom oraz Anonimowym Recenzentom, których uwagi i sugestie pozwoliły na znaczne udoskonalenie artykułu. Dziękuję za wnikliwość i staranność.

\section{Literatura}

Abernathy R., 1970, Cemeteries as Open Space Reservations, Reed-Mullins and Associates, U.S.

Department of Housing and Urban Development, Washington DC.

American Planning Association, 1952, Cemeteries in the city plan report.

Ariès P., 1989, Cistowiek i smierć, PIW, Warszawa.

Balon J., 2005, Miejsce i rola kościotów w krajobrazie polskiego Podtatræa, [w:] A. Szponar, S. Horska-Schwarz (red.), Struktura præestrzenno-funkcjonalna krajobrazu, Problemy Ekologii Krajobrazu, XVII, Wrocław, 183-193.

Bednarczyk M., Rapiński J., 2011, Wykorzystanie oprogramowania open source w pomiarach bezpośrednich na przyktadzie systemu Quantum GIS, Roczniki Geomatyki, 9 (3), 25-35.

Capels V., Senville W., 2006, Planning for cemeteries, Planning Commissioners Journal, 64, 1-8. Chudak M., 2012, Cmentaræe jako specyficzne nieruchomości w præestrzeni miasta (przyktad Les:na), Świat Nieruchomości, 3 (81), 56-61.

Croucamp L., Richards N., 2002, Guidelines for cemetery site selection, Council for Geoscience, Pretoria. 
Długozima A., 2011, Cmentarze jako ogrody ṡywych i umarłych, Wydawnictwo Sztuka krajobrazu, Warszawa.

Długozima A., 2014, Miejsce i rola cmentarzy w budowaniu krajobrazu sakralnego wsi, na przykładzie Bieszczadów $i$ Warmii, Teka Komisji Architektury, Urbanistyki i Studiów Krajobrazowych Polska Akademia Nauk - Oddział w Lublinie, X (1), 5-19.

Długozima A., Kosiacka-Beck E., 2020, How to Enhance the Environmental Values of Contemporary Cemeteries in an Urban Context?, Sustainability, 12 (6), 2374, 1-19.

Durecka I., 2017, Parki jako element struktury præestræennej miast Łódzkiego Obszaru Metropolitalnego, Łódź [maszynopis].

Dydkowski G., Tomanek R., 2005, Charakterystyka transportu zbiorowego w matych i średnich miastach w Polsce, [w:] K. Heffner (red.), Mate miasta a rozwój lokalny i regionalny, Wydawnictwo Akademii Ekonomicznej w Katowicach, Katowice, 209-218.

Francaviglia R., 1971, The cemetery as an evolving cultural landscape, Annals of the Association of American Geographers, 61 (3), 501-509.

Francis D., 2003, Cemeteries as cultural landscapes, Mortality, 8, 222-227.

Gilbert Q.L., 1991, The Ecology of Urban Habitats, Chapman and Hall, New York.

Harvey T., 2006, Sacred Spaces, Common Places: The Cemetery in the Contemporary American City, Geographical Review, 96 (2), 295-312.

Kjøller Ch.P., 2012, Managing green spaces of the deceased: characteristics and dynamics of Danish cemetery administrations, Urban Forestry \& Urban Greening, 11 (3), 339-348.

Kjøller Ch.P., 2013, Cemeteries - organisation, management and innovation: diffusion of maintenance specifications in Danish national church cemetery administrations, Department of Geosciences and Natural Resource Management, Faculty of Science, University of Copenhagen.

Kolbuszewski J., 1996, Cmentaræe, Wydawnictwo Dolnośląskie, Wrocław.

Komornicki T., 2013, Propozycje wskazników powiqzań, [w:] P. Śleszyński (red.), Wskazniki zagospodarowania i ładu præestræennego w gminach, Biuletyn KPZK PAN, 252, 164-175.

Komornicki T., Śleszyński P., Rosik P., Pomianowski W., 2009, Dostęność przestrzenna jako præestanka ksжtattowania polskiej polityki transportowej, Biuletyn KPZK, 241.

Laske D., 1994, Cemeteries: Ecological Niches in Populated Areas, Naturwissenschaften, 81, 218-223.

Lehrer J.D., 1974, Cemetery Land Use and the Urban Planner, Urban Law Annual. Journal of Urban and Contemporary Law, 7, 181-197.

Michalak J., 2007, Otwarte oprogramowanie i otwarte dane w geomatyce, Roczniki Geomatyki, 5 (2), 11-20.

Moonen J., 2009: Cemetery For The City. Creating an Urban Integrated Cemetery For The City Of Maassluis, https://repository.tudelft.nl/islandora/object/uuid\%3A5d5dc0d3-58f0-423c-a17297a36a0a30f4 (data dostępu: 5.12.2019).

Myślińska A., 2018, Grzebowiska dla zwierzqt w Polsce, Architectus, 1 (53), 89-98.

NIK, 2016, Zaræqd:anie cmentaræami komunalnymi. Informacja o wynikach kontroli, https://www. nik.gov.pl/plik/id,12230,vp,14613.pdf (data dostępu: 5.12.2019). 
Piątkowska K., 1983, Ksstałtowanie obiektów $i$ zespotów ustugowych. Zieleń $i$ wypoczynek, Instytut Kształtowania Środowiska, Warszawa.

Pogodziński Z., 1975, Planowanie præestrzenne terenów wiejskich, PWN, Warszawa.

Ptaszycka A., 1950, Przestrzenie zielone w miastach, Wydawnictwo Ludowa Spółdzielnia Wydawnicza Oddział w Poznaniu, Poznań.

Richter G., 1995, Kryteria planowania sieleni na cmentaræach, [w:] O. Czerner, I. Juszkiewicz (red.), Cemetery art-Sztuka cmentarna - l'art de cimetiere, Wyd. ICOMOS, Wrocław, 201-205.

Rogowska B., 2014, Stanowisko wtad komunistycznych w latach siedemdziesiatych XX wieku w zakresie cmentarnictwa wyznaniowego i komunalnego, Annales Universitatis Paedagogicae Cracoviensis. Studia Politologica, XIII, 75-93.

Rosporzqdzenie Ministra Gospodarki Komunalnej z 25 sierpnia 1959 roku w sprawie określenia, jakie tereny pod waględem sanitarnym sq odpowiednie na cmentarze, Dz. U. z 1959 roku, Nr 52, poz. 315.

Rosporzqdzenie Ministra Infrastruktury \& dnia 7 marca 2008 roku w sprawie wymagań, jakie musะq spetniać cmentarze, groby i inne miejsca pochówku zwtok i szczqtków, Dz. U. 2008, Nr 48, poz. 284.

Rosporzqdzenie Rady Ministrów z dnia 30 grudnia 1999 roku w sprawie Polskiej Klasyfikacji Obiektów Budowlanych (PKOB), Dz.U. Nr 112, poz. 1316.

Rugg J., 2000, Defining the place of burial: what makes a cemetery a cemetery, Mortality, 5 (3), 259-275.

Santarsiero A., Cutilli D., Cappiello G., Minelli L., 2000, Environmental and Legislative Aspects Concerning Existing and New Cemetery Planning, Microchemical Journal, 67 (1-3), 141-145.

Śleszyński P., 2014, Dostępność czasowa i jej æastosowania, Przegląd Geograficzny, 86 (2), 171-215.

Sobczak A., 2003, Poradnik cmentarny. Kościelne i cywilne normy prawne o cmentarzach i chowaniu smartych, wraz \& or:ecznictwem, Gaudentinum, Gniezno.

Solarek K., 2009, Funkcje terenów zieleni kształtujacych przestrzenie publiczne we wspótczesnym mieście, Przegląd Komunalny, 10 (82), 71-76.

Stępa M., 1993, Przestrzenne aspekty kremacji, Praca doktorska napisana na Politechnice Gdańskiej, Gdańsk [maszynopis].

Studium uwarunkowań i kierunków zagospodarowania przestrzennego miasta Luboń, 2008, Uchwała nr XXIII/129/2008, Rada Miasta Luboń z dnia 25 września 2008.

Swaryczewska M., 2008, Sacrum i profanum w krajobrazie kulturowym. Dziedzictwo præestrzeni sakralnej na Warmii, Wydawnictwo Uniwersytetu Warmińsko-Mazurskiego w Olsztynie, Olsztyn.

Syndicat Intercommunal Funéraire de la Région Parisienne (Intercommunal Funeral Syndicate of the Paris Region), 2016, Situation et enjeux des cimetières intercommunaux.

Szukalski P., 2016, Liczba «gonów w Polsce w przysztości, Demografia i Gerontologia SpołecznaBiuletyn Informacyjny, 3, 1-4.

Szumański M., 2005, Strukturalizacja terenów zieleni, Wydawnictwo SGGW, Warszawa.

Tanaś S., 2008, Przestræeń turystyczna cmentarzy. Wstęp do tanatoturystyki, Wydawnictwo Uniwersytetu Łódzkiego, Łódź. 
Thomas L.V., 1991, Trup. Od biologii do antropologii, Wydawnictwo PIW, Łódź.

Tudor C.A., Iojă I.C., Hersperger A., Pătru-Stupariu I., 2013, Is the residential land use incompatible with cemeteries location? Assessing the attitudes of urban residents, Carpathian Journal of Earth and Environmental Sciences, 8 (2), 153-162.

Ustawa z 31 stycznia 1959 o cmentarzach i chowaniu smartych, Dz. U. 1959, Nr 11, poz. 62.

Ustawa \& dnia 16 kwietnia 2004 roku o ochronie przyrody, Dz. U. 2004, Nr 92, poz. 880.

Ustawa z dnia 28 marca 1933 roku o grobach i cmentarzach wojennych, Dz. U. 1933, Nr 39, poz. 311.

Ustawa z dnia 7 lipca 1994 roku Prawo budowlane, Dz. U. 1994, Nr 89, poz. 414.

Van Steen P.J.M., Pellenbarg P.H., 2006, Death and space in the Netherlands, Journal of Economic and Social Geography, 97, 623-635.

Ziobrowski Z., 2012, Urbanistyczne wymiary miast, Instytut Rozwoju Miast, Kraków.

Anna Dtugozima

Sækota Gtówna Gospodarstwa Wiejskiego w Warsæawie,

Wydziat Budownictwa i Insynierii Środowiska,

Instytut Inżynierii Środowiska, Katedra Sztuki Krajobrazu,

ul. Nowoursynowska 166, 02-787 Warszawa

anna_dlugozima@sggw.pl 